\title{
Prevalence, structure and properties of subsurface chlorophyll maxima in Canadian Arctic waters
}

\author{
Johannie Martin ${ }^{1, *}$, Jean-Éric Tremblay ${ }^{1}$, Jonathan Gagnon ${ }^{1}$, Geneviève Tremblay ${ }^{2}$, \\ Amandine Lapoussière ${ }^{2}$, Caroline Jose $^{2}$, Michel Poulin $^{3}$, Michel Gosselin², \\ Yves Gratton ${ }^{4}$, Christine Michel ${ }^{5}$ \\ ${ }^{1}$ Québec-Océan \& Département de biologie, Université Laval, Québec, Québec G1V 0A6, Canada \\ ${ }^{2}$ Institut des sciences de la mer (ISMER), Université du Québec à Rimouski, Rimouski, Québec G5L 3A1, Canada \\ ${ }^{3}$ Canadian Museum of Nature, Ottawa, Ontario K1P 6P4, Canada \\ ${ }^{4}$ Institut National de Recherche Scientifique, Centre Eau, Terre et Environnement, Québec, Québec G1K 9A9, Canada \\ ${ }^{5}$ Freshwater Institute, Fisheries and Oceans Canada, Winnipeg, Manitoba R3T 2N6, Canada
}

\begin{abstract}
Comprehensive investigations of the Canadian Arctic during late summer and early fall revealed the widespread occurrence of long-lived subsurface chlorophyll maxima (SCM) in seasonally ice-free waters. The vertical position of the SCM corresponded with the depth of the subsurface biomass maximum (SBM), at least in Baffin Bay, suggesting that SCM could be an important source of carbon for the food web. Most of these SCM were located well below the pycnocline in close association with the nitracline, implying that their vertical position was driven mainly by a shortage of inorganic nitrogen in the upper euphotic zone. The diversity of SCM configurations with respect to physical properties of the water column complicates the estimation of euphotic-zone chlorophyll and primary production from surface properties. High photosynthetic yields $\left(F_{\mathrm{v}} / F_{\mathrm{m}}\right)$ showed the phytoplankton to be photosynthetically competent and well acclimated to conditions of irradiance and nutrient supply near the surface and at the SCM. A well-defined primary nitrite maximum was associated with the SCM in the southwest Canadian Arctic, but not in the northeast where nitrite concentrations were highest much below the euphotic zone. This contrast is consistent with differences in vertical stratification, the light-dark cycle and, possibly, the physiological state and taxonomic composition of the phytoplankton community at the SCM. This study demonstrates that the SCM, once regarded as anecdotal due to under-sampling, are a dominant feature of the Arctic Ocean that should be considered in remote sensing studies and biogeochemical models.
\end{abstract}

KEY WORDS: Subsurface chlorophyll maximum $\cdot$ Deep chlorophyll maximum $\cdot$ Subsurface biomass maximum $\cdot$ Phytoplankton $\cdot$ Arctic $\cdot$ Nutrients $\cdot$ Nitrogen $\cdot$ Photosynthetic yield

Resale or republication not permitted without written consent of the publisher

\section{INTRODUCTION}

The spatial distribution of marine phytoplankton is highly heterogeneous. On the vertical, subsurface maxima of chlorophyll (SCM) or biomass (SBM) are common under stratified conditions (Cullen 1982, Coon et al. 1987). Their vertical position is regarded as a compromise between nutrient limitation near the surface and light limitation at depth: a situation that should favor shade-adapted phytoplankton species with the lowest requirements for light (i.e. compensation irradiance; Huisman et al. 2006). The SCM have been found to harbor up to an order of magnitude the concentration of chlorophyll a $(\mathrm{chl} a)$ found at the surface (Steele 1964, Anderson 1969, Klausmeier \& Litchman 2001, Sharples et al. 2001) and to be dominated numerically by few algal species (Coon et al. 1987, Huszar et al. 2003). Their existence poses a challenge to the remote-sensing estimation of primary production (e.g. Uitz et al. 2006). 
Phytoplankton biomass at a given depth is the net result of local production, death by lysis or grazing and the gains and losses imparted by passive or active motion of the cells (e.g. Dolan \& Marrasé 1995, Klausmeier \& Litchman 2001, Fennel \& Boss 2003, Hodges \& Rudnick 2004, Holm-Hansen \& Hewes 2004, Huisman et al. 2006, Beckmann \& Hense 2007, Sharples et al. 2007). Vertical decoupling of the SBM and SCM is not rare and has been ascribed to photoacclimation, whereby the ratio of chl a to carbon increases with depth to optimize light harvesting (Steele 1964, Kiefer et al. 1976, Cullen 1982, Falkowski \& Kiefer 1985, Fennel \& Boss 2003). Most observational studies investigate only the SCM with high-resolution profiling of chlorophyll fluorescence and ignore the SBM since the visual estimation of biomass from microscopic enumeration and sizing of phytoplankton is tedious, and discrete sampling may miss the SBM altogether. Transmissometers can be used to pinpoint the SBM in clear waters where particulate beam attenuation $\left(C_{\mathrm{p}}\right)$ in the red part of the light spectrum is strongly influenced by microbial organisms (Chung et al. 1998), but the procedure is unreliable under the influence of river discharge or sediment resuspension in coastal waters.

SCM are persistent in perennially stratified tropical and subtropical waters (Huisman et al. 2006, Mann \& Lazier 2006) and seasonal at high latitudes in the Southern Ocean (Holm-Hansen \& Hewes 2004) and the boreal North Atlantic, where the extensive mixing of the water column during fall and winter replenishes the surface with nutrients (Mann \& Lazier 2006). This phenomenon permits the development of a spring bloom in the upper euphotic zone and a seasonal succession whereby a transient SCM community replaces the fast-growing bloomers once nutrients are exhausted from the surface (Mann \& Lazier 2006, Pommier et al. 2009). In the High Arctic, the seasonal ice cover and extreme solar cycle restrict the productive period to a few months (Sakshaug 2004). Unlike the North Atlantic, the periodic renewal of nutrients in the upper euphotic zone is often tempered by the ice cover and the strong vertical stability imparted by seasonal melt and the horizontal inputs of freshwater from large rivers and low-salinity water from the Pacific Ocean (Jones et al. 2003, Stein \& Macdonald 2004, Tremblay et al. 2008).

In the Beaufort Sea, convection and winds have a minor disrupting effect on stratification during fall and winter (Tremblay et al. 2008). Exceptions to this pattern are found in productive polynyas (e.g. the North Water; Tremblay et al. 2002) and along the margin of shallow continental shelves when upwelling-favorable winds blow under conditions of reduced ice cover (Williams \& Carmack 2008). The low initial inventories of nitrate in the surface mixed layer are readily used in spring, which rapidly induces nitrogen limitation above the nutricline (e.g. Franklin Bay, Tremblay et al. 2008). The SCM form within days of the ice break-up and hypothetically persist throughout summer, mediating a large portion of the annual nitrate drawdown. Despite their implications for food webs, biogeochemical fluxes and the accuracy of remote sensing estimates of primary production, SCM have only been briefly mentioned in observational studies of subarctic and Arctic primary production (e.g. Martini 1986, Hirche et al. 1991, Cota et al. 1996, Heiskanen \& Keck 1996, Lee \& Whitledge 2005), and their overall function, structure and significance have not been assessed.

Here we report on the large-scale incidence and properties of SCM in the Canadian High Arctic, the subarctic Hudson Bay and a few Labrador fjords. Surveys were conducted during late summer and early fall to ensure that all regions had lost their seasonal ice cover and the pelagic growth season was underway. Our working hypothesis is that SCM are photosynthetically competent and associated with favorable conditions of allochthonous nitrate supply, not merely a change in chl a content per unit of carbon. This hypothesis is validated here by a near-synoptic comparison of intrinsic SCM characteristics (i.e. vertical position, chl a concentration, taxonomic composition and photosynthetic competency) with the physical structure of the water column and the vertical distribution of oxygen and macronutrients in contrasted environments. A second objective was to assess if the inventory of chl $a$ in the euphotic zone can be predicted from surface values in the context of remote sensing.

\section{MATERIALS AND METHODS}

Sampling. The 2005 (16 August to 16 October) and 2006 (4 September to 4 November) expeditions of the RV 'CCGS Amundsen', covered the entire latitudinal and longitudinal swath of the Canadian Archipelago, including Baffin Bay, the Northwest Passage, the Beaufort Sea, Foxe Basin, Hudson Bay and 3 Labrador fjords (Fig. 1) at a total of 219 stations. Vertical profiles were obtained with a CTD rosette equipped with sensors to measure in vivo fluorescence (SeaPoint Chlorophyll Fluorometer), transmissivity (WET Labs CST671DR), dissolved oxygen (Sea-Bird SBE43), nitrate (SATLANTIC ISUS V1), photosynthetically active radiation (PAR; Biospherical QCP-2300), and temperature and salinity (Sea-Bird SBE-911plus).

At a subset of 140 stations (55 in 2005 and 85 in 2006), water samples for nutrient determinations (nitrate $\left[\mathrm{NO}_{3}{ }^{-}\right]+$nitrite $\left.\left[\mathrm{NO}_{2}^{-}\right]\right)$, phosphate $\left(\mathrm{PO}_{4}{ }^{3-}\right)$ and silicic acid $\left(\mathrm{Si}(\mathrm{OH})_{4}\right)$ were taken with 12 l Niskin type 


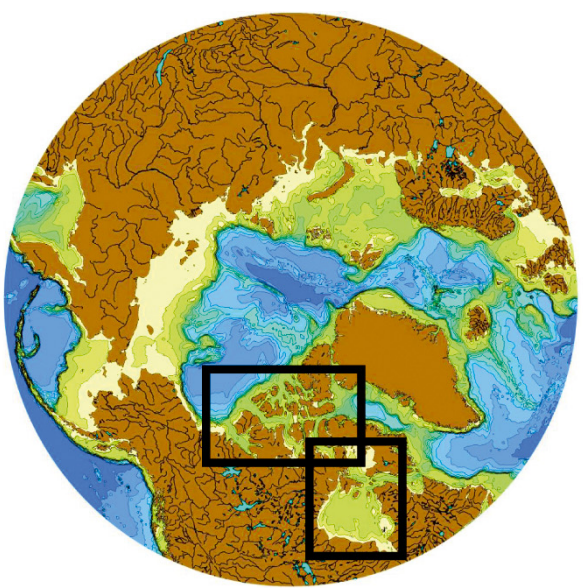

2005
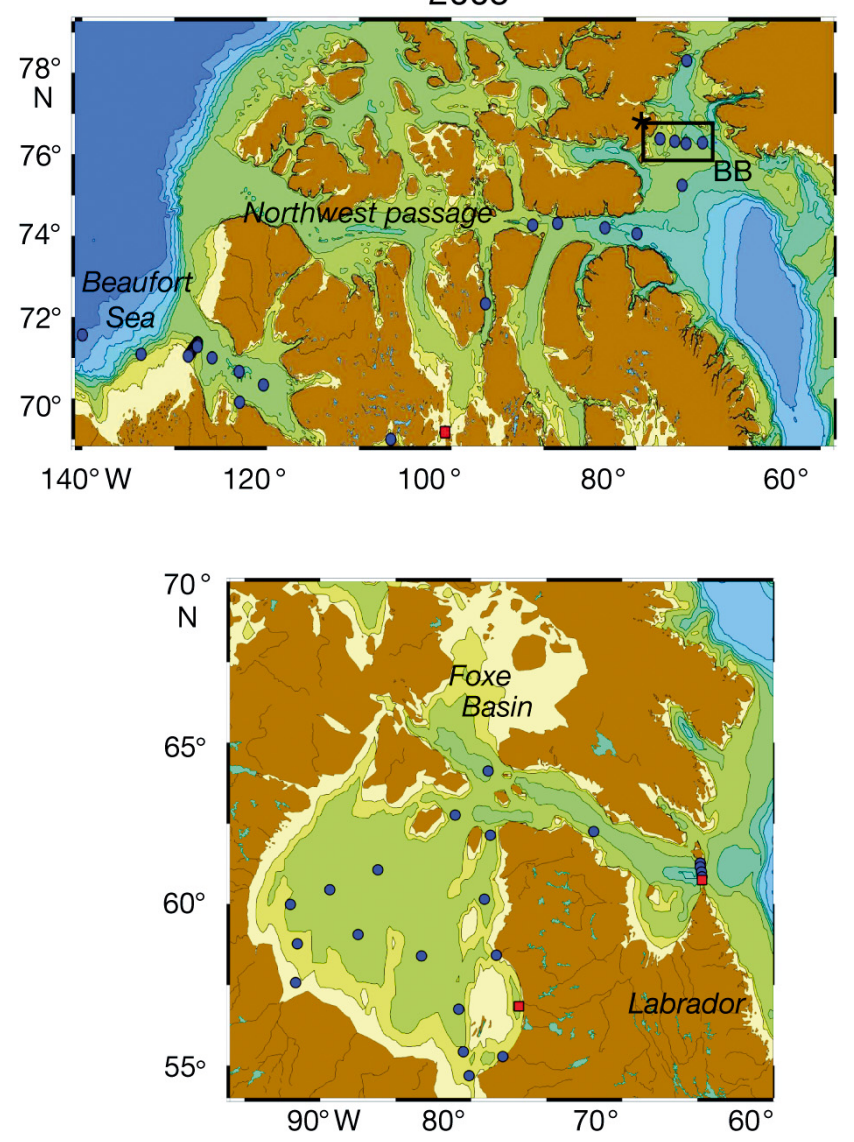

bottles attached to the CTD rosette at standard depths $(5,10,20,30,40,50,60,70,80,100,125,150,175,200$, 250, $300 \mathrm{~m}$ and then every $100 \mathrm{~m}$ ) unless the Arctic halocline was identified on the CTD downcast. In this case, sampling in the 100-200 m range occurred at every $20 \mathrm{~m}$ and at a salinity of 33.1 to capture the nutrient maximum. Out of those 140 stations, 64 (35 in 2005 and 29 in 2006) were also sampled for ammonium $\left(\mathrm{NH}_{4}{ }^{+}\right)$, chl $a$, and photosynthetic yield. Samples for chl $a$ and photosynthetic yield were taken at 5 depths:
Fig. 1. Location of sampling stations with the presence (blue circles) or absence (red squares) of a subsurface fluorescence maximum in the Canadian Arctic during 2005 (left-hand panels) and 2006 (right-hand panels). Four oceanographic sections are identified within boxes: southeast Beaufort Sea (BS; 5-6 Oct 2006), Amundsen Gulf (AG; 29 Sep-18 Oct 2006), Barrow Strait/Lancaster Sound (LS; 20-25 Sep 2006) and northern Baffin Bay (BB; 16-22 Aug 2005). Stars represent the starting point of the sections presented in Figs. 5 and 6

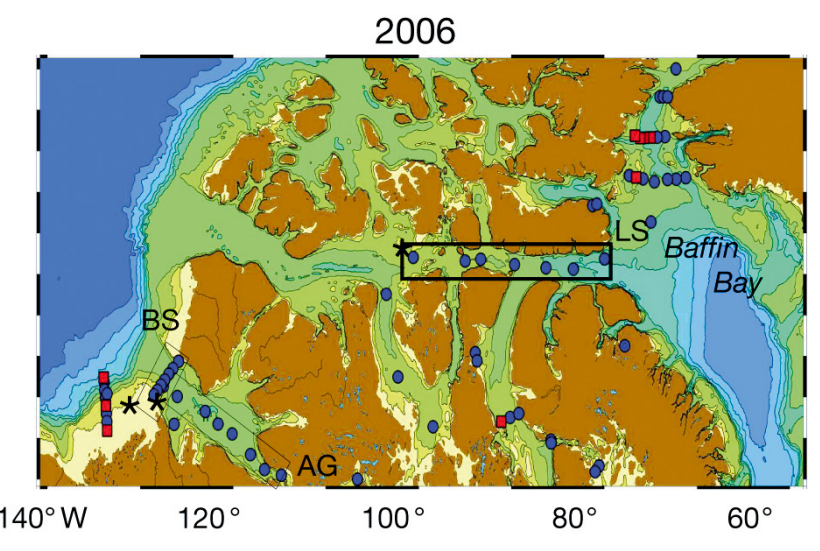

Depth

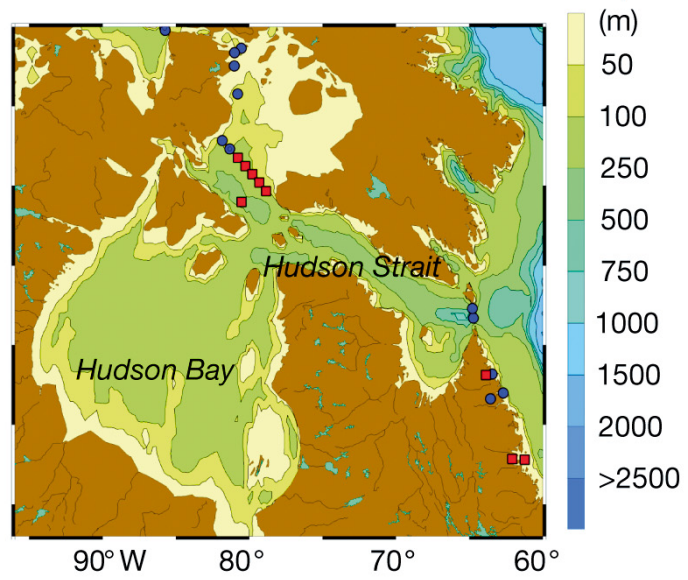

in the upper mixed layer (5 m), in the lower and upper trails of the SCM, at the SCM, and below the euphotic zone. Samples for phytoplankton identification and enumeration were collected at the depth of the SCM at 35 stations in 2005 (all regions) and at 15 stations in 2006 (Baffin Bay, Northwest Passage, and Beaufort Sea).

Nutrients. Samples for nutrient determination were collected into acid-cleaned polyethylene tubes after thorough rinsing and filtration through a $5 \mu \mathrm{m}$ polycar- 
bonate filter inserted in a filter holder. This step insured the removal of the large particles (e.g. clay, mud) and organisms that may interfere with the analyses. Samples were stored at $4^{\circ} \mathrm{C}$ in the dark and analyzed within a few hours for $\mathrm{NO}_{2}{ }^{-}, \mathrm{NO}_{3}{ }^{-}+\mathrm{NO}_{2}{ }^{-}, \mathrm{PO}_{4}{ }^{3-}$ and $\mathrm{Si}(\mathrm{OH})_{4}$ using standard colorimetric methods (Grasshoff et al. 1999) adapted for the AutoAnalyzer 3 (Bran+Luebbe). $\mathrm{NH}_{4}{ }^{+}$was determined manually with the sensitive fluorometric method of Holmes et al. (1999). The working reagent was added within minutes of sampling. The detection limit for $\mathrm{NH}_{4}{ }^{+}$analysis was $0.02 \mu \mathrm{M}$ or better.

Extracted chlorophyll and photosynthetic competency. Concentrations of chl a were determined using the fluorometric method described by Parsons et al. (1984). Samples were filtered onto Whatman GF/F filters and extracted with $90 \%$ acetone for $18 \mathrm{~h}$ at $4^{\circ} \mathrm{C}$ in the dark. The fluorescence was measured before and after acidification with a Turner Designs Model 10-AU fluorometer.

The photosynthetic competency (i.e. maximum photochemical quantum yield of photosystem II $=F_{\mathrm{v}} / F_{\mathrm{m}}$ ) of the algae was estimated by pulse-amplitude-modulated fluorometry (WALZ Phyto-PAM). This method is based on the induction and detection of chlorophyll fluorescence, which provides the minimum $\left(F_{\text {oi }}\right.$ near-darkness condition) and maximum ( $F_{\mathrm{m}}$ s saturation pulse of $200 \mu \mathrm{s}$ at $4000 \mu \mathrm{mol}$ quanta $\mathrm{m}^{-2} \mathrm{~s}^{-1}$ ) fluorescence required for the computation of variable fluorescence $\left(F_{\mathrm{v}}=F_{\mathrm{m}}-F_{\mathrm{o}}\right)$. Samples were dark-adapted for $30 \mathrm{~min}$ at $\sim 4^{\circ} \mathrm{C}$ (Ban et al. 2006; no significant correlation was observed between $F_{\mathrm{v}} / F_{\mathrm{m}}$ and in situ temperature at the depth of collection) to allow relaxation of fluorescence quenching. A blank was assessed at each station with SCM water filtered through a $0.2 \mu \mathrm{m}$ syringe filter. To minimize the effect of taxonomic variability, fluorescence was measured at 3 specific wavelengths $(470,520$, and $645 \mathrm{~nm})$. Emissions at $645 \mathrm{~nm}$ (wavelength for allophycocyanin and phycocyanin: specific pigments of cyanobacteria) were close to background noise so that only the 470 and $520 \mathrm{~nm}$ emissions (wavelengths for $\mathrm{chl} a, b$ and $c$, fucoxanthin and carotenoids; specific pigments of diatoms, dinoflagellates and green algae) were averaged for the calculation of $F_{\mathrm{v}} / F_{\mathrm{m}}$. There was no relationship between chl a concentration and $F_{\mathrm{v}} / F_{\mathrm{m}}$.

Phytoplankton abundance and taxonomic composition. For the identification and enumeration of phytoplankton, samples were preserved with acidic Lugol's solution (Parsons et al. 1984). Cells $\geq 4 \mu \mathrm{m}$ were identified to the lowest possible taxonomic rank using an inverted microscope (WILD Heerbrugg) equipped with phase contrast optics (Lund et al. 1958). For each sample, a minimum of 300 cells was counted. The main references used for phytoplankton identification were Tomas (1997) and Bérard-Therriault et al. (1999).
Sensor calibrations and data transformations. Detailed vertical profiles of water temperature, salinity, transmissivity, PAR, oxygen and in vivo fluorescence were analyzed for 219 stations. The CTD and attached sensors were factory calibrated prior to each expedition. Analytically determined $\mathrm{NO}_{3}{ }^{-}$concentrations were used to post-calibrate the optical nitrate probe and generate high-resolution vertical profiles. Due to problems with the batteries of the probe and with problematic calibrations at a few stations, detailed $\mathrm{NO}_{3}{ }^{-}$profiles were only available for 147 stations. The output of the oxygen sensor was frequently calibrated against Winkler titrations (modified as in Carpenter 1965, and automated as described in Knapp et al. 1990) and proved to be reliable and stable over time. The degree of oxygen saturation was calculated using in situ concentration and theoretical solubility based on temperature and salinity data (Weiss 1970). The Brunt-Väisälä (or buoyancy) frequency $\left(N^{2}=\left\{[g / \rho \mathrm{d} \rho / \mathrm{d} z]^{1 / 2}\right\}^{2}\right.$; in $\mathrm{s}^{-2}$ and where $g$ is the gravitational acceleration) was estimated from the difference in potential density $(\rho)$ between consecutive depth $(z)$ intervals. The pycnocline and nitracline were defined as the depth where $N^{2}$ and the vertical gradient in $\mathrm{NO}_{3}{ }^{-}$concentration $\left(\mathrm{dNO}_{3}{ }^{-} / \mathrm{d} z\right)$ were highest, respectively. The depth of the SCM was defined as the depth where the in vivo fluorescence was at a maximum, while its thickness was estimated as the zone of elevated fluorescence between areas where the mean vertical gradient in in vivo fluorescence $(\mathrm{d}($ in vivo fluorescence)/dz) was zero over 5 consecutive depth bins.

Due to highly variable weather conditions (cloud cover) and because the ship did not stay at any station for more than a few hours, a comparison of sampling sites on the basis of absolute irradiance at the SCM was not practical. Instead, we made these comparisons using the coefficient of diffuse light attenuation $(k)$, which is a more stable property of the water column over time scales of a few days at least. The percentage of incident PAR available at the SCM was calculated from the value of $k$ determined between the surface and the SCM using vertical PAR profiles. In this paper, we arbitrarily define the base of the euphotic zone as the $1 \%$ of surface irradiance to facilitate comparisons with the literature.

Ordinary least-squares regressions (model I linear regression) were used to determine predictive relationships (e.g. equations used in the reconstruction of chl a profiles; post-calibrations) and geometric mean regressions (considering error on both variables; model II linear regression) were used to assess functional relationships between 2 variables (Laws \& Archie 1981, Wallace et al. 1995, Calbet \& Prairie 2003). 


\section{RESULTS}

Subsurface fluorescence maxima were widespread in the Canadian High Arctic, Hudson Bay and Labrador fjords during late summer 2005 and early fall 2006 (Fig. 1). Out of 140 stations, 85\% clearly showed a subsurface maximum, which ranged broadly in vertical position ( 7 to $67 \mathrm{~m}$; median: $29 \mathrm{~m}$ ) and thickness ( 2 to $74 \mathrm{~m}$; median: $18 \mathrm{~m}$ ). The other stations $(15 \%$ ) showed vertically homogenous fluorescence (shallow Foxe Basin; 7 to147 m) or a surface maximum (western Baffin Bay, Mackenzie Shelf, inner Canadian Archipelago, Hudson Bay and Labrador fjords).

Using the average output of the fluorometer during bottle closure, the relationships between in vivo fluorescence and extracted chl a concentration were assessed separately for each region and expedition (e.g. for Baffin Bay in 2006: $\left.y=1.05 x-0.08 ; \mathrm{n}=39, \mathrm{r}^{2}=0.92, \mathrm{p}<0.0001\right)$. The small residuals of the regressions showed an even dispersal for concentrations ranging at least 2 orders of magnitude, and intercepts were statistically undistinguishable from zero, indicating negligible interferences or quenching near the surface. Region-specific relationships were used to construct high-resolution vertical profiles of chl $a$. To determine if $c_{\mathrm{p}}(\lambda \approx 660 \mathrm{~nm})$ is an acceptable surrogate for phytoplankton biomass in Baffin Bay, the biovolume-based estimates of total autotrophic carbon biomass reported by Booth et al. (2002) (determined by epifluorescence microscopy enumeration and sizing) were compared with concomitant transmissometer data (Fig. 2). Strong linear relationships were observed between $c_{\mathrm{p}}$ and the carbon biomass of total phytoplankton and diatoms. This exercise was not attempted in the shallow Canadian Archipelago and the coastal Beaufort Sea due to the proximity of the Mackenzie River and resuspension on shallow shelves.

The depths of the SCM, the SBM and the oxygen saturation maximum (SOM) were compared in northern Baffin Bay (Fig. 3), where river runoff has a negligible influence on particle load. In 2006 (when the oxygen probe worked consistently and the spatial coverage of northern Baffin Bay was extensive), the vertical depth of the SCM closely matched those of the SBM (when detectable; i.e. when the particle load in surface waters was negligible) and of the SOM. A positive relationship between the depths of the SCM and SOM was also observed in the Beaufort Sea but was much weaker $\left(\mathrm{r}^{2}=0.24, \mathrm{n}=61\right)$ than in Baffin Bay.

\section{General conditions at the SCM}

The frequency distributions of physical properties and nitrogenous nutrient concentrations at the SCM depth are presented in Fig. 4. Although irradiance at

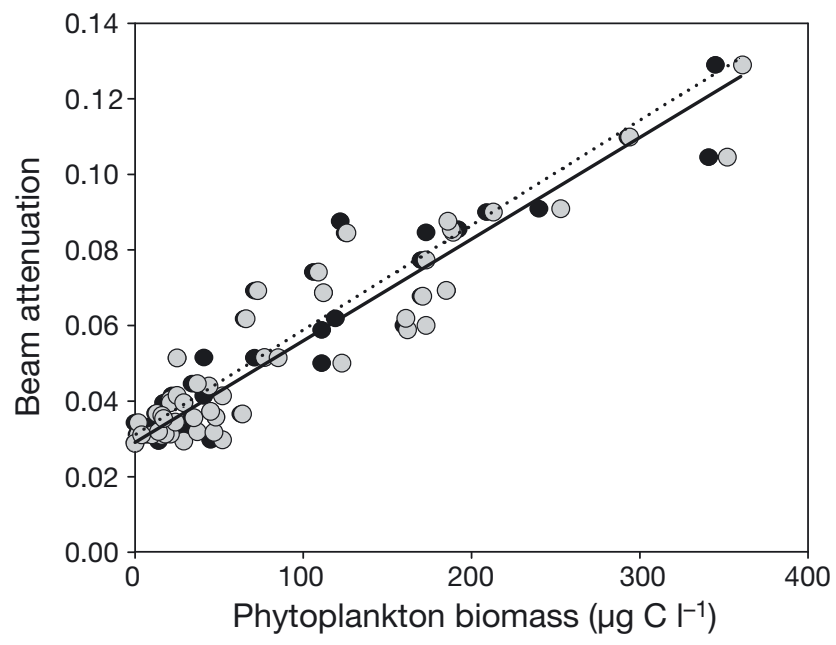

Fig. 2. Relationships between particulate beam attenuation $\left(C_{\mathrm{p}}\right)$ and phytoplankton carbon estimates in northern Baffin Bay (data from late summer 1998; Booth et al. 2002). Model II linear regressions: $y=0.0003 x+0.03, \mathrm{n}=53, \mathrm{r}^{2}=0.88$ (diatom carbon; black circles, dotted line) and $y=0.0002 x+0.03, n=$ $53, r^{2}=0.88$ (total autotrophic carbon; gray circles, solid line)

the SCM ranged from 0.001 to $48 \%$ of surface values (daily mean absolute irradiance corresponding to 0.0006-75.12 $\mu \mathrm{mol}$ quanta $\mathrm{m}^{-2} \mathrm{~s}^{-1}$ assuming that the mean irradiance along the ship track during a day is representative of a given station), $83 \%$ (181 out of 219 CTD stations) of the SCM were located below the $10 \%$ light level and the mode of the distribution (52\% of the stations) was in the 3 to $10 \%$ range (Fig. $4 \mathrm{~A}$ ). Water temperature ranged from -1.5 to $2.0^{\circ} \mathrm{C}$ at $83 \%$ of the

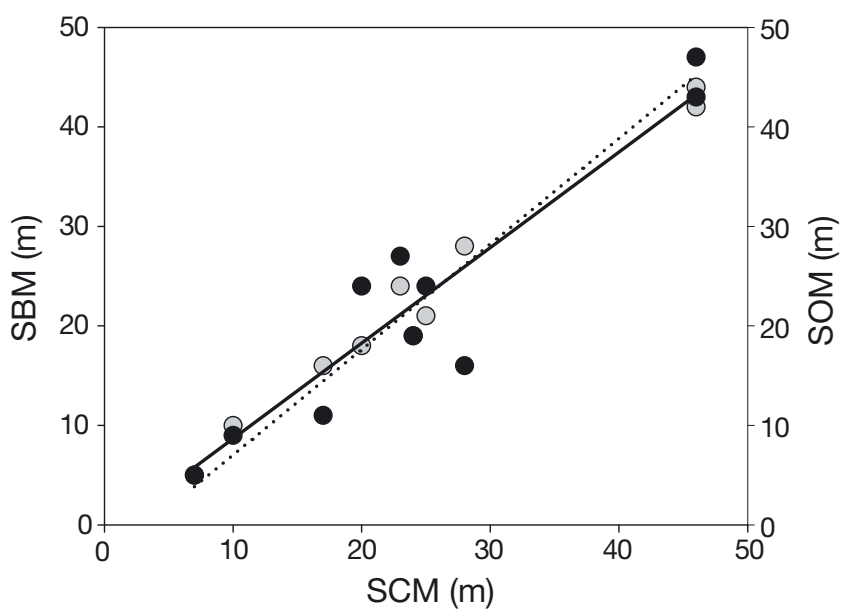

Fig. 3. Relationships between vertical position of the subsurface chlorophyll maximum (SCM), subsurface biomass maximum (SBM; gray circles) and oxygen saturation maximum (SOM; black circles) for northern Baffin Bay stations in 2006. Model II linear regressions between SBM and SCM depths (solid line: $y=0.96 x-0.93 ; \mathrm{n}=10, \mathrm{r}^{2}=0.98$ ) and between SOM and SCM depths (dotted line: $y=1.06 x-3.57 ; \mathrm{n}=10$, $\left.\mathrm{r}^{2}=0.88\right)$ 

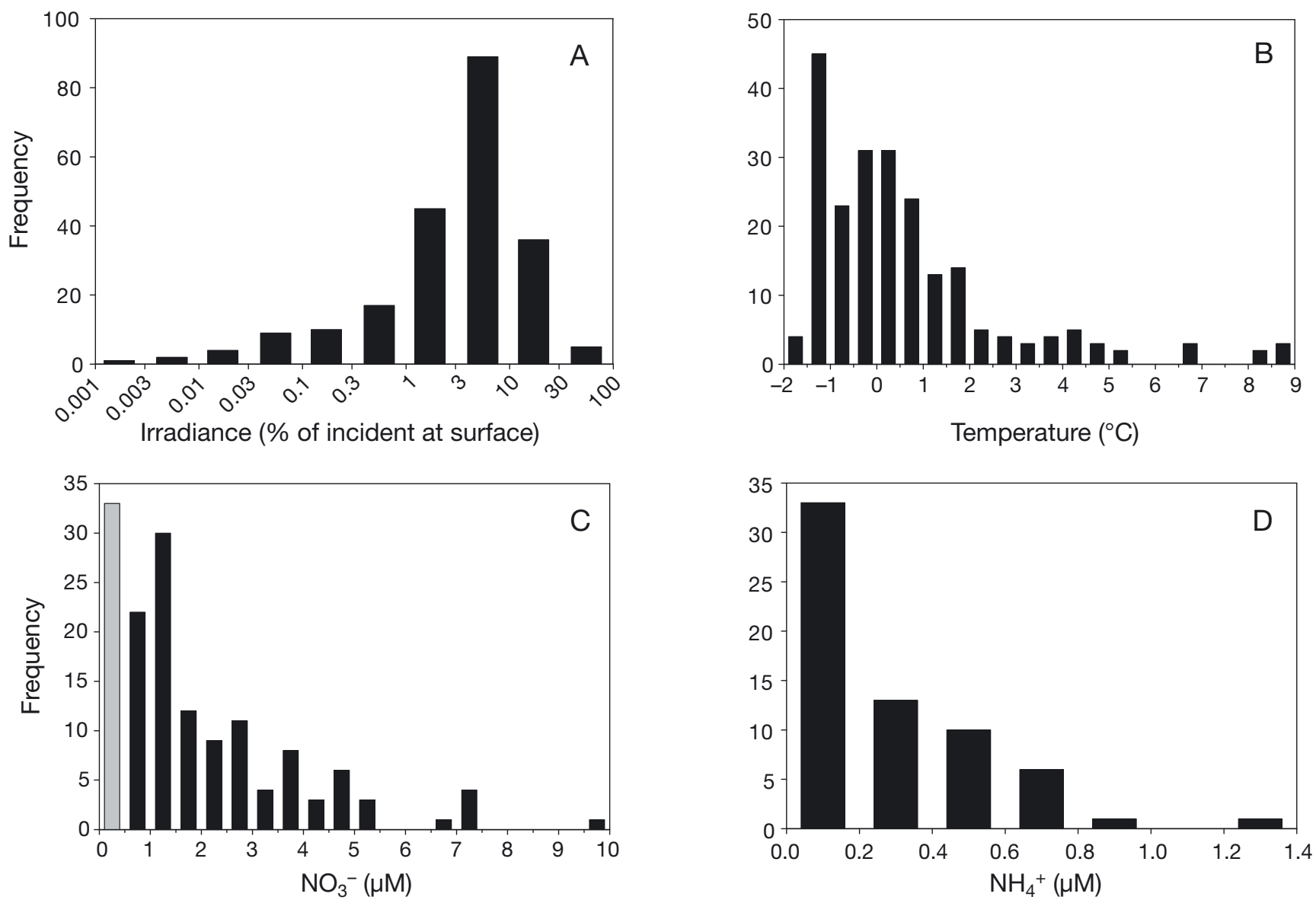

Fig. 4. Frequency distributions of (A) percentage of surface irradiance, (B) water temperature, (C) $\mathrm{NO}_{3}{ }^{-}$and (D) $\mathrm{NH}_{4}{ }^{+}$concentrations at the depth of the subsurface chlorophyll maximum (SCM). In (C), gray bar = samples below the analytical limit of detection (i.e. $<0.05 \mu \mathrm{M}$ ). All sampling stations and years were pooled

stations (181 out of 219 CTD stations), with a mode between -1.5 and $-1.0^{\circ} \mathrm{C}$ (at $21 \%$ of stations; Fig. 4B). Extreme values of -1.8 and $9^{\circ} \mathrm{C}$ were observed in isolated instances. Nitrate concentrations generally ranged from 0.5 to $3.0 \mu \mathrm{M}$ with values $<0.5 \mu \mathrm{M}$ or $>3 \mu \mathrm{M}$ at 22 and $20 \%$ of the stations, respectively (Fig. 4C). $\mathrm{NH}_{4}{ }^{+}$concentrations varied between the detection limit $(0.02 \mu \mathrm{M})$ and $1.40 \mu \mathrm{M}$ with a mode of $0.20 \mu \mathrm{M}$ at $52 \%$ of the stations (Fig. 4D).

\section{Oceanographic sections}

The positioning of the SCM relative to vertical profiles of nutrients and the physical structure of the water column was explored in detail using 4 oceanographic sections (see Fig. 1 for locations). Concentrations of chl $a$ at the SCM were generally lower in the western sections (Beaufort Sea [BS]: 0.32 to $0.74 \mu \mathrm{g} \mathrm{l^{-1 }}$; Amundsen Gulf [AG]: 0.34 to $2.50 \mu \mathrm{g} \mathrm{l}^{-1}$ ) than in the eastern sections (Lancaster Sound [LS]: 0.53 to $4.52 \mu \mathrm{g} \mathrm{l}^{-1}$;
Baffin Bay [BB]: 1.39 to $16.65 \mu \mathrm{g} \mathrm{l}^{-1}$ ) (Fig. 5). There was no consistent regional difference in the depth of the SCM, which most often occurred between 20 and $35 \mathrm{~m}$. Conspicuous exceptions were noted off the shelf break on the BS section (40 to $62 \mathrm{~m}$ ), at the entrance of LS $(70 \mathrm{~m}$ ) and at 3 stations on the LS and BB sections (12 to $15 \mathrm{~m})$. The SCM was at or well above the $1 \%$ surface irradiance in all but 4 stations on the sections. Chl a concentration generally declined to very low values $\left(<0.1 \mathrm{Mg}^{-1}\right)$ below the SCM, except in northern BB where they remained moderate $\left(>0.5 \mu \mathrm{g} \mathrm{l}^{-1}\right)$ in the upper $80 \mathrm{~m}$ of the water column.

The pycnocline (i.e. depth with the maximum value of $N^{2}$ ) was shallow nearly everywhere (14 to $32 \mathrm{~m}$ ) but the stratification was stronger in the western sections (i.e. BS and AG) than in the eastern ones (i.e. LS and BB) (Fig. 6A). The pycnocline was systematically located in the upper euphotic zone and most often above the SCM. Oxygen saturation was generally $>100 \%$ at the SCM, with maximum values generally observed at or close to the SCM (Fig. 6B). $\mathrm{NO}_{3}{ }^{-}$ 
concentrations were generally near the analytical detection limit above the SCM, which was typically associated with the top of the nitracline (Fig. 6C). Note that $\mathrm{Si}(\mathrm{OH})_{4}$ and $\mathrm{PO}_{4}{ }^{3-}$ concentrations (not shown) followed the same vertical patterns as $\mathrm{NO}_{3}{ }^{-}$, but were not depleted in the surface layer. Maximum $\mathrm{NO}_{2}{ }^{-}$concentrations were much higher in the western sections than in the eastern ones (Fig. 6D). A well-defined primary $\mathrm{NO}_{2}{ }^{-}$maximum (PNM) was visible only in the western sections, where it generally tracked the SCM. In the eastern sections, the layer of elevated $\mathrm{NO}_{2}{ }^{-}$concentration was relatively diffuse and thick with no apparent relationship with the $\mathrm{SCM}$. On all sections, $\mathrm{NH}_{4}{ }^{+}$ concentrations were uniformly low in surface waters and generally showed a subsurface maximum below the SCM (Fig. 6E). Subsurface concentrations were particularly high in the eastern sections (up to $1.24 \mu \mathrm{M}$ ) and elevated $\mathrm{NH}_{4}{ }^{+}$concentrations extended far below the euphotic zone in northern BB.

\section{Light attenuation, nutrients and vertical position of the SCM}

The relationship between the vertical position of the SCM and $k$ for all stations is shown in Fig. 7A. The range of $k$ went from a minimum of $0.046 \mathrm{~m}^{-1}$ at deep stations to a maximum of $0.475 \mathrm{~m}^{-1}$ at neritic stations influenced by large rivers (Fig. 7A). To remove this influence, a model II linear regression was adjusted for stations with $k<0.15 \mathrm{~m}^{-1}$ and showed a very weak $\left(\mathrm{r}^{2}=0.14\right)$, negative relationship between the 2 variables (Fig. 7A).

The SCM was deeper than the pycnocline at $86 \%$ of the stations and no significant correlation was observed between their respective vertical positions (Fig. 7B). However, $68 \%$ of the stations showed a vertical match between the depth of the SCM and the nitracline within a margin of $\pm 10 \mathrm{~m}$ (Fig. 7C). This match extended to $90 \%$ of the stations for a margin of $\pm 20 \mathrm{~m}$. A linear regression fit trough all data evidenced 16 large residuals (standardized residuals $\geq 2$; belonging to stations with poorly defined SCM or nitracline) that belonged to either very weakly stratified stations (maximum $N^{2} \leq 0.0006$ ) or sites where the nitracline was more than $12 \mathrm{~m}$ below the $1 \%$ of surface irradiance (Fig. 7C). The regression was largely improved by removing the outliers from the analysis. To verify if light penetration through the upper water column improved the relationship, a multivariate linear regression model considering the depth of the SCM, $k\left(x_{1}\right)$ and the depth of the nitracline $\left(x_{2}\right)$ was adjusted to stations where $k<0.15 \mathrm{~m}^{-1}$ (minus the 16 outliers). A relationship was obtained $\left(y=-36.67 x_{1}+\right.$ $\left.0.775 x_{2}+10.92 ; r^{2}=0.67, p_{1}=0.2260, p_{2}<0.0001\right)$, but the regression coefficient for $k$ was not significant.

\section{Photosynthetic competency}

Considering the entire sampling area, data from 2005 and 2006 generally displayed high $F_{\mathrm{v}} / F_{\mathrm{m}}$ at the SCM (median: 0.56) although values varied between 0.32 and 0.70 (Fig. 8). At the surface, $F_{\mathrm{v}} / F_{\mathrm{m}}$ ranged from 0.08 to 0.71 with a median value of 0.55 (Fig. 8). The scatter of values was much lower at the SCM than at the surface (where $F_{\mathrm{v}} / F_{\mathrm{m}}$ was frequently $<0.45$ ) and there was no statistically significant difference between the 2 sampling depths (Wilcoxon signed rank test, $\mathrm{p}=0.542$ ).
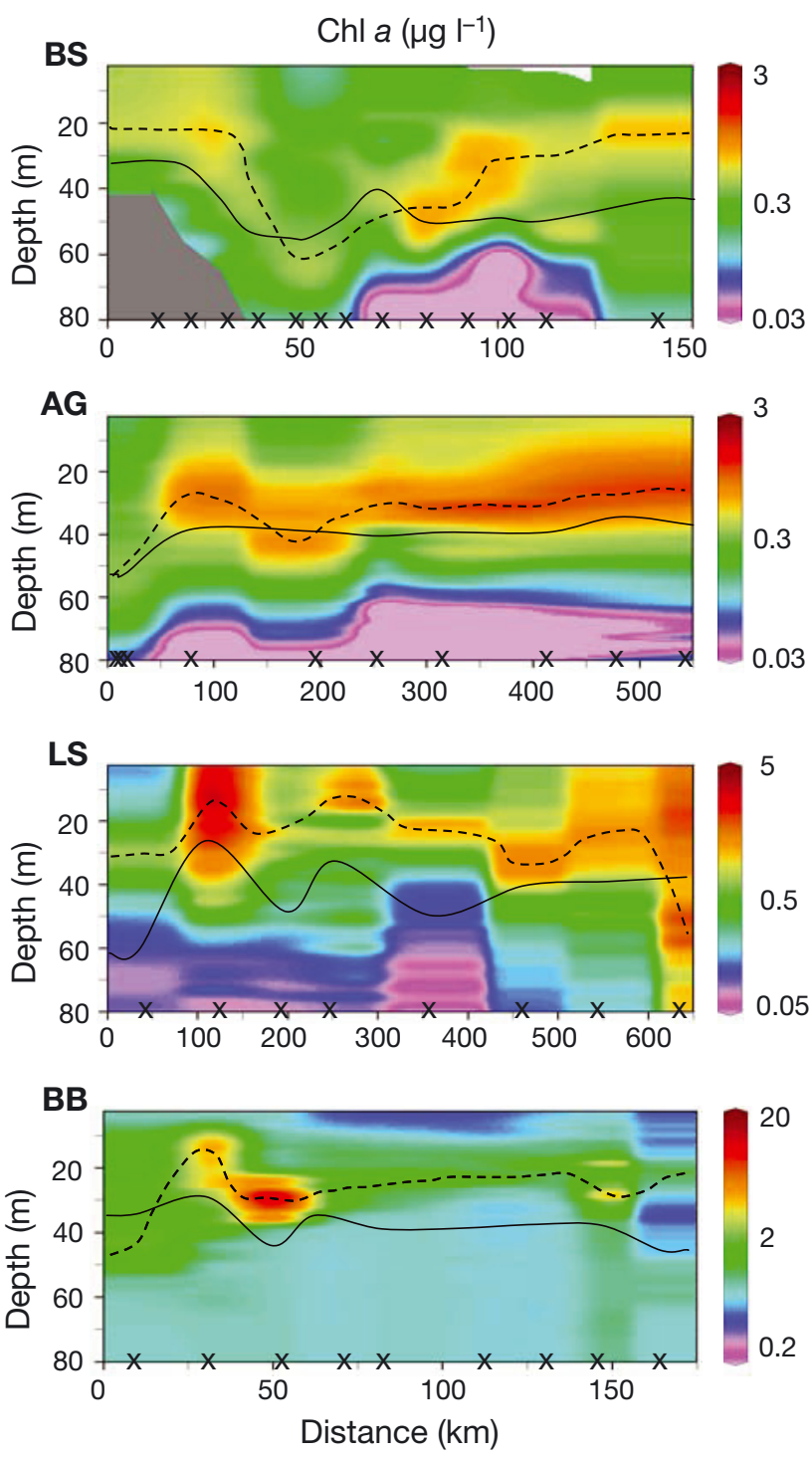

Fig. 5. Vertical variations of calibrated chl a concentration (right-hand color key) along sections in BS, AG, LS and BB (see Fig. 1 for exact locations). Dashed and solid lines: depths of the subsurface chlorophyll maximum and of the euphotic zone (defined here as $1 \%$ of surface irradiance), respectively.

Position of each sampling station: ' $\mathrm{x}$ ' on the bottom axis 

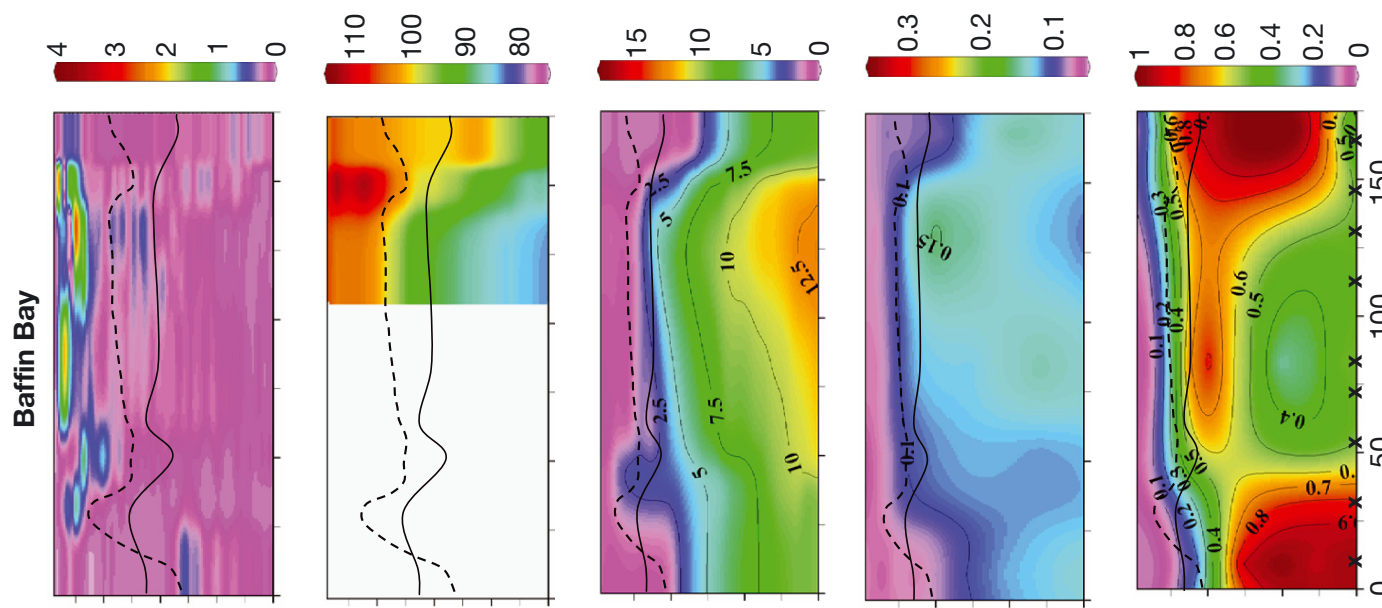

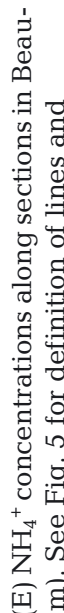
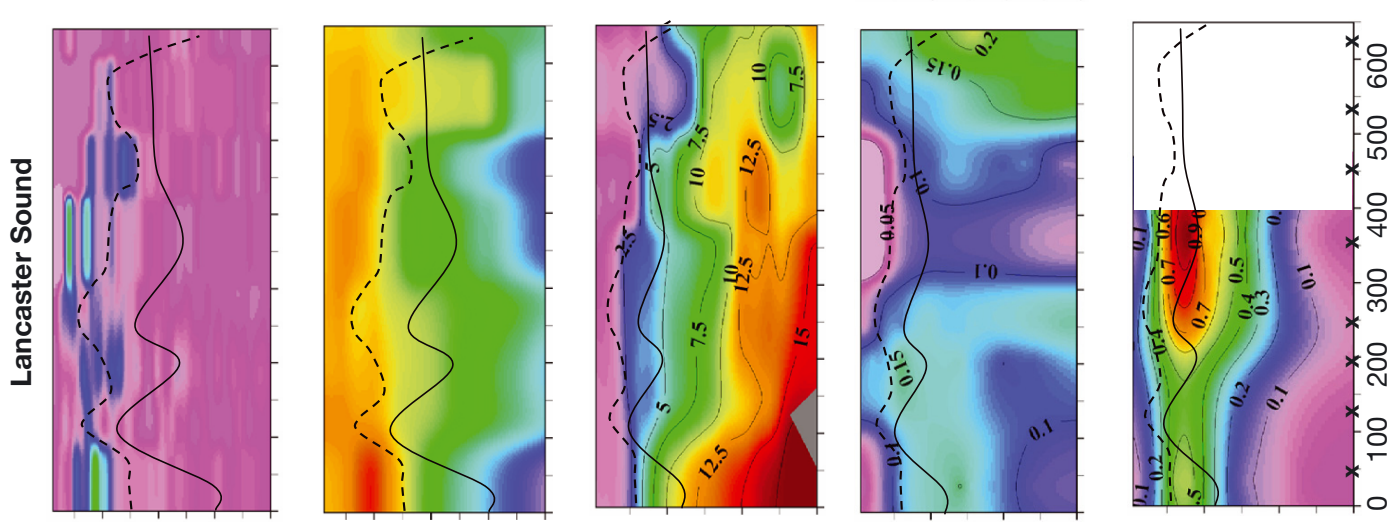

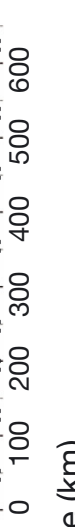
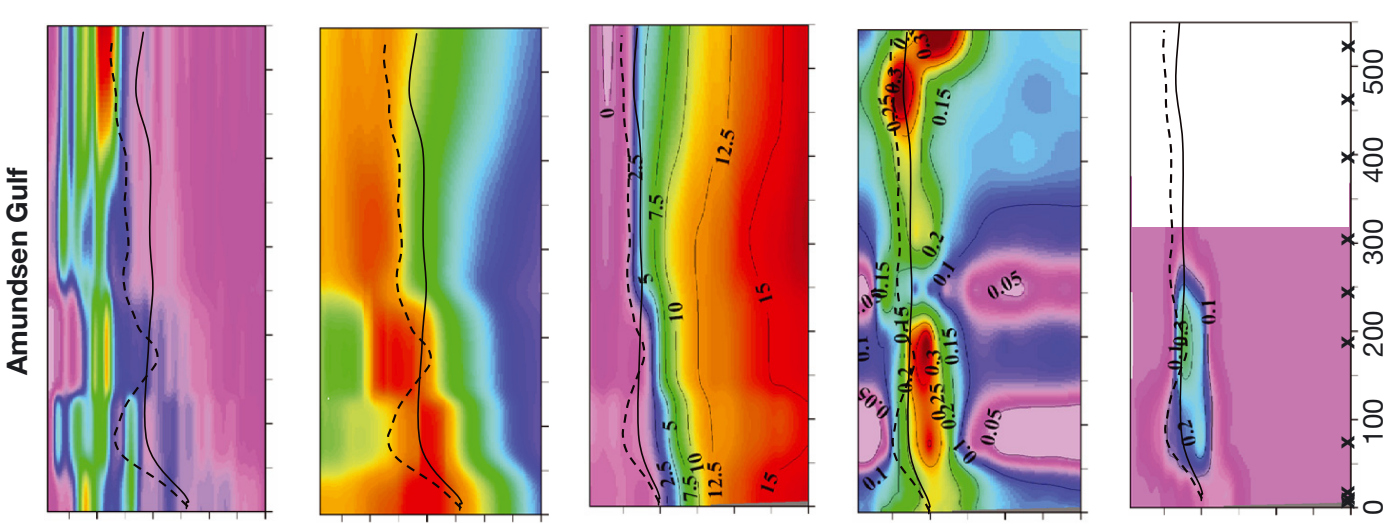

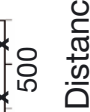

임

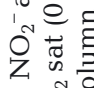

อ.

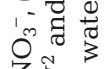

芝艺岁

Uิ

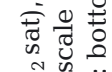

象运

苟苟

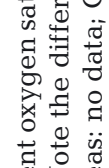
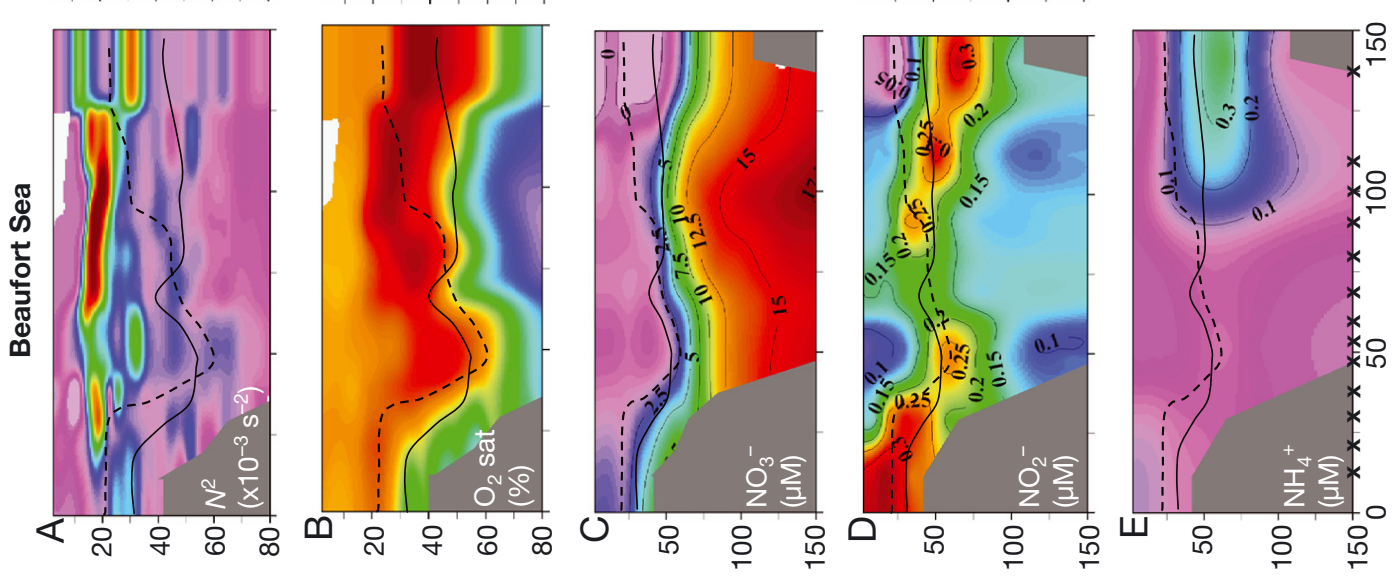

这

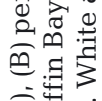

空要

究 है है

द्व

正

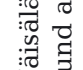
Depth $(\mathrm{m})$ 

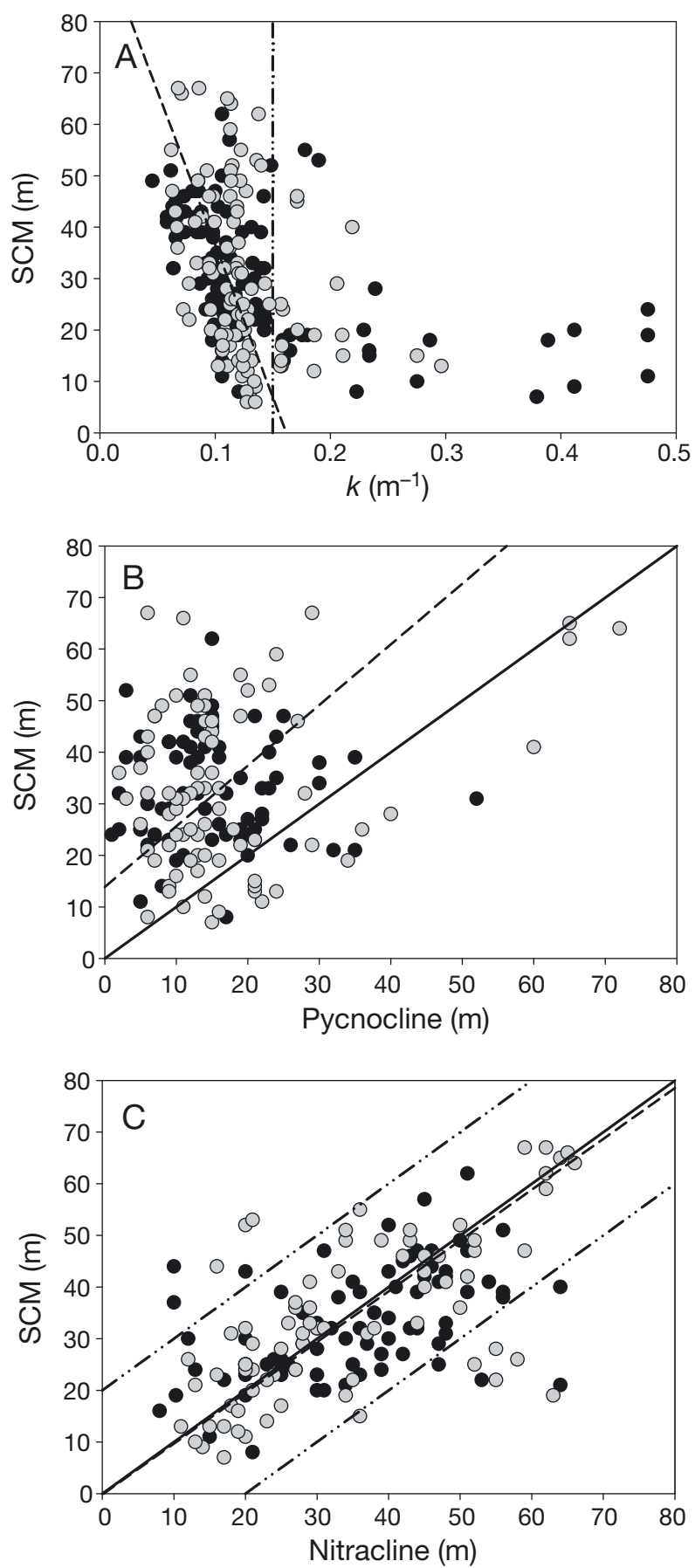

Fig. 7. Relationships between depth of the subsurface chlorophyll maximum (SCM) and (A) the coefficient of diffuse light attenuation $(k)$, (B) the pycnocline, and $(C)$ the nitracline in 2005 (black circles) and 2006 (gray circles). In (A), vertical dash-dotted line: $k=0.15 \mathrm{~m}^{-1}$ (see 'Results: Light attenuation, nutrients and vertical position of the $\mathrm{SCM}^{\prime}$ for details); and dashed line: model II linear regression for stations, where $k<0.15 \mathrm{~m}^{-1}\left(y=-594.5 x+96.18 ; \mathrm{r}^{2}=0.14\right)$. In (B) and $(\mathrm{C})$, solid line indicates 1:1 match; and dashed line: model II linear regression between SCM and pycnocline depths $(y=1.18 x+$ $\left.13.86 ; r^{2}=0.04\right)$ and between SCM and nitracline depths $(y=$ $0.98 x-0.16 ; \mathrm{r}^{2}=0.66$ when excluding 16 outliers). Dashdotted lines in $(\mathrm{C})$ represent 1:1 $\pm 20 \mathrm{~m}$

\section{Taxonomic composition at the SCM}

The taxonomic composition of the phytoplankton at the SCM was investigated for both sampling years (Fig. 9). The relative abundance of flagellates and dinoflagellates was 21 and $38 \%$ lower, respectively, in 2006 than in 2005 in all regions. During both years, the BS presented lower percentage of diatoms and higher percentages of flagellates and dinoflagellates than northern BB. Flagellates and dinoflagellates were numerically dominant in the Hudson Bay system in 2005 and made up, on average, $90 \%$ of the total phytoplankton abundance. In all regions, centric diatoms were, on average, 3 to 27 times more abundant than pennate diatoms. Except in the Hudson Bay system, Chaetoceros spp. were the most abundant centric diatoms at the SCM in 2005 and 2006 (76 to 99\% of total centric diatoms on average). Chaetoceros socialis Lauder was present at $56 \%$ of the stations and represented up to $30 \%$ of the total Chaetoceros abundance. However, C. socialis was less abundant in 2006 than in 2005. Diatoms of the genus Thalassiosira were scarce throughout the Canadian Arctic (0 to $0.5 \%$ ).

Pearson's product moment correlations (PPMC) were used to evaluate relationships between environmental variables and the relative and absolute abundance data. Only the significant correlations are described here. At the SCM, the absolute abundance of flagellates increased with $\mathrm{NH}_{4}{ }^{+}$concentration ( $\mathrm{r}=0.48, \mathrm{p}<$ $0.01)$. The relative abundance of dinoflagellates increased with $N^{2}(\mathrm{r}=0.32, \mathrm{p}<0.05)$, whereas the relative abundance of pennate diatoms increased with $\mathrm{NO}_{2}{ }^{-}$concentration $(\mathrm{r}=0.39, \mathrm{p}<0.01)$. The relative dominance of diatoms over flagellates decreased with water temperature $(r=-0.34, p<0.05)$ and increased with ambient $\mathrm{NO}_{3}{ }^{-}$concentration $(\mathrm{r}=0.31, \mathrm{p}<0.05)$.

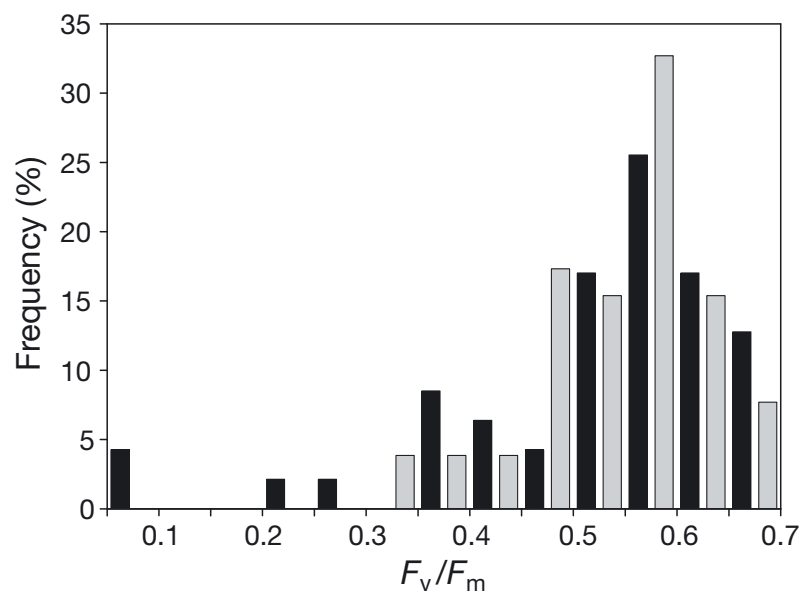

Fig. 8. Frequency distribution of $F_{\mathrm{v}} / F_{\mathrm{m}}$ at the surface (black) and at subsurface chlorophyll maximum (gray). All sampling stations and years were pooled 
Beaufort Sea

2005

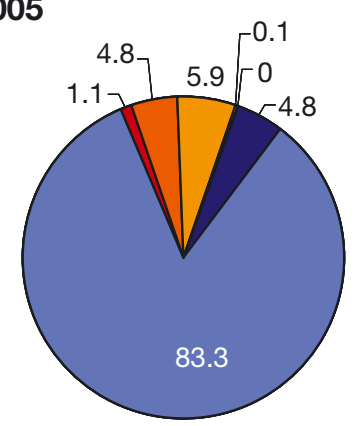

2006

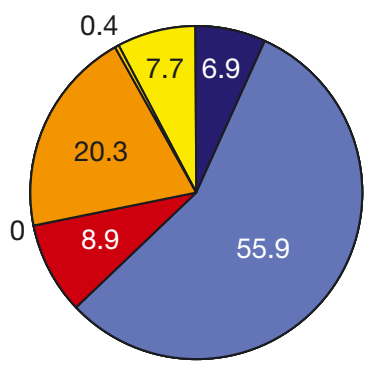

Canadian Archipelago
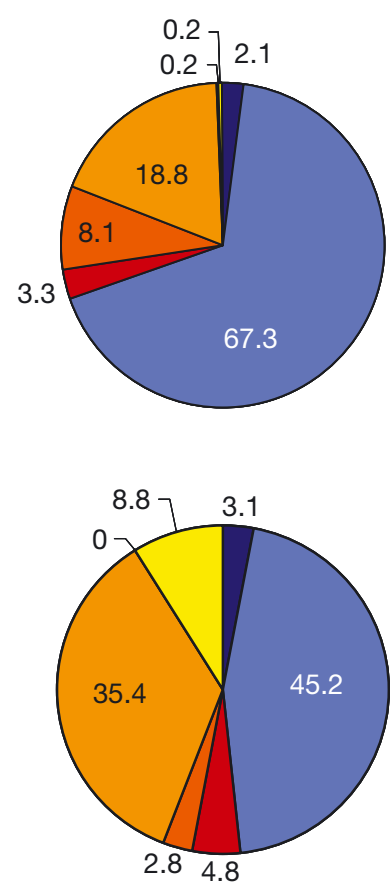

Baffin Bay
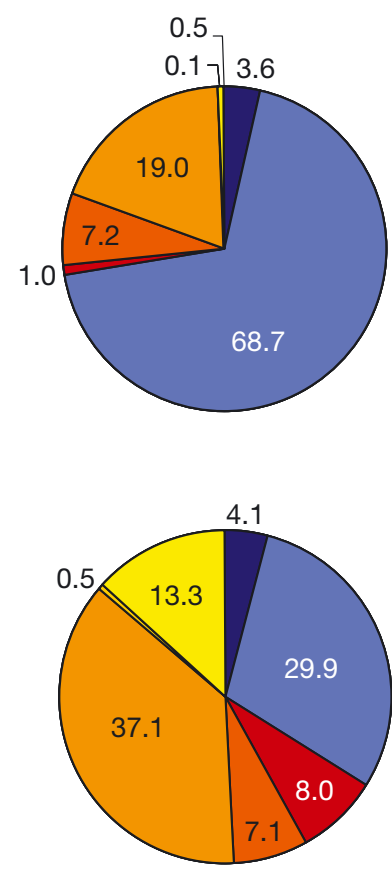

Hudson Bay
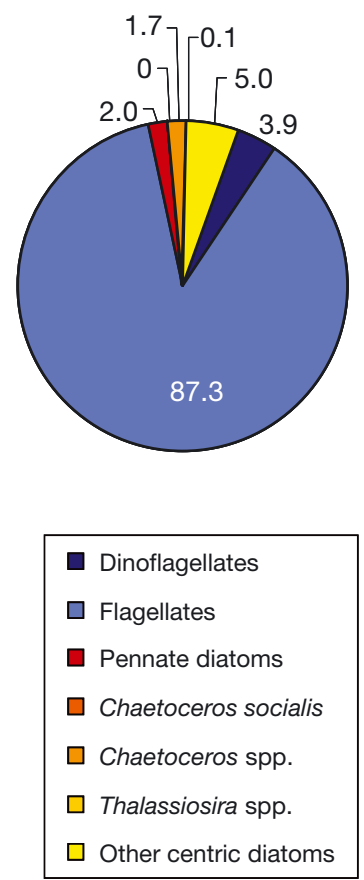

Fig. 9. Mean percent abundance of the major phytoplankton groups observed at the depth of the subsurface chlorophyll maximum in the Beaufort Sea, inner Canadian Archipelago, northern Baffin Bay and Hudson Bay in 2005 and 2006 . Hudson Bay was not sampled in 2006

$\mathrm{NO}_{3}{ }^{-}$concentration was positively correlated to $\mathrm{NO}_{2}{ }^{-}$ concentration $(\mathrm{r}=0.52, \mathrm{p}<0.001)$ and salinity $(\mathrm{r}=0.30$, $\mathrm{p}<0.05)$.

\section{DISCUSSION}

This study provides the first near-synoptic assessment of the incidence and properties of SCM through the Canadian Arctic, including the subarctic Hudson Bay and Labrador fjords, during late summer and early fall. Results show that SCM are almost ubiquitous and imply that they persist throughout the ice-free period since they are known to appear early in the growth season (Booth et al. 2002, Tremblay et al. 2008). Now that the prevalence of SCM is established, their characteristics will be discussed with respect to the physico-chemical structure of the water column, potential repercussions for the estimation of primary production by remotesensing and biogeochemical implications.

The absence of SCM was noted only near rivers and at shallow locations $(<100 \mathrm{~m})$ where vertical mixing or upwelling is important (Fig. 1). For example, the shallow water column $(<100 \mathrm{~m})$ on the eastern side of Foxe Basin is completely mixed by $8 \mathrm{~m}$ tides (Prinsenberg 1986). Chl a was usually highest at the surface at very weakly stratified (western BB, Hudson Strait) and shallow (Canadian Archipelago, eastern Hudson Bay, Mackenzie Shelf and Labrador fjords) stations. Otherwise, chl a concentrations at the SCM were in agreement with sparse reports for the same regions or other sectors of the North-American Arctic (Cota et al. 1996, Vidussi et al. 2004, Lee \& Whitledge 2005).

Concentrations of chl $a$ at the SCM were relatively low (0.1-2.5 $\mathrm{\mu g}^{-1}$ ) in LS, AG and the southeast BS, where values generally increased from deep offshore waters to the shelf. The depth of the SCM was also quite variable. Off the shelf break, where $\mathrm{NO}_{3}{ }^{-}$was depleted in the upper euphotic zone, SCM were as deep as $62 \mathrm{~m}$. This result can be explained by the strong stratification, which is not broken down during winter and limits the upward supply of nutrients all year long (Tremblay et al. 2008). Near the coast, some SCM were as shallow as 8 to $20 \mathrm{~m}$ where nutrient concentrations in the upper part of the water column were elevated due to enhanced local mixing (e.g. internal waves; Sharples et al. 2007) and mild shelf-break upwelling (Carmack \& Chapman 2003)(Fig. 6). By contrast, chl a concentrations at the SCM in BB were generally high $\left(1.4 \mu \mathrm{g}^{-1}\right.$ in the east to $16.7 \mu \mathrm{g} \mathrm{l}^{-1}$ in the west), even over relatively deep waters. The most diffuse SCM on the vertical occurred in eastern BB 
where the stratification was weakest. A similar situation occurred at the eastern edge of LS, which received relatively well-mixed waters from the north. Overall, the high variability in SCM characteristics was better explained by regional differences in stratification than by local properties (e.g. nutrient concentration, light availability) at the actual depth of the SCM on any given day. This result suggests that the mixing regime in the lower euphotic zone exerts a determinant influence on upward nutrient fluxes and the intensity and shape of SCM in the Canadian Arctic.

\section{Implications of SCM for remote sensing}

Using surface concentration to predict the shape of the vertical profile of chl $a$ and its total stock in the euphotic zone is desirable for monitoring purposes and to estimate primary production from space. Algorithm for the remote-sensing estimation of primary production in the Arctic Ocean typically assume homogenous chl $a$ in the upper mixed layer and an exponential decrease underneath (e.g. Arrigo et al. 2008). This assumption is adequate early in the growth season, especially in highly productive waters, but the biases it introduces where SCM prevail throughout most of summer and fall remain to be assessed. In first analysis, the coefficient of variation for chl a concentration was 2 -fold higher at the SCM (143\%) than at the surface $(76 \%)$, implying that the high heterogeneity at depth was not well expressed at the surface. To investigate further, we compared our dataset with 2 predictive models established for other regions of the world ocean (Fig. 10; Morel \& Berthon 1989, Uitz et al. 2006). These models describe the non-linear relationships between the mean concentration of chl a over the first penetration depth of orbiting sensors (depth of $1 \%$ of surface irradiance $\div 4.6$ ) in Case I waters with (1) the total chl a inventory in the euphotic zone and (2) the shape of the standardized vertical chl a profile.

Surface chl a explained $65 \%(p<0.0001)$ of integrated chl $a$ in the euphotic zone, and the weak, significant relationship shown in Fig. 10A agrees broadly with Morel \& Berthon (1989) and Uitz et al. (2006). However, applying these general regressions indiscriminately to the Arctic can (1) overestimate chl a inventories by 2 - to 3 -fold at neritic stations (Fig. 10B) or (2) underestimate it by a factor of 3 to 5 in relatively clear, stratified waters with a pronounced SCM (Fig. 10C). The overestimation (Fig. 10B) is not surprising since it occurs in turbid waters not considered by these regressions, i.e. where river runoff and shallow bathymetry severely restrict the thickness of the euphotic zone (Fig. 10A: black circles outside of the lower $95 \%$ confidence line). The underestimation (Fig. 10A,C: circles outside the upper 95\% confidence line) is explained by the relationships shown in Figs. 6A \& 7B,C. As the SCM seasonally lowers the nitracline well beneath the thin upper mixed layer in clear waters, it becomes physically disconnected from the surface and resides in the upper halocline, where a moderate density gradient limits turbulent dispersion.

\section{Implications of SCM for primary production in the Arctic}

Because SCM usually occur in the lower euphotic zone, errors in the assumed vertical distribution of chlorophyll are likely to translate into lesser errors for
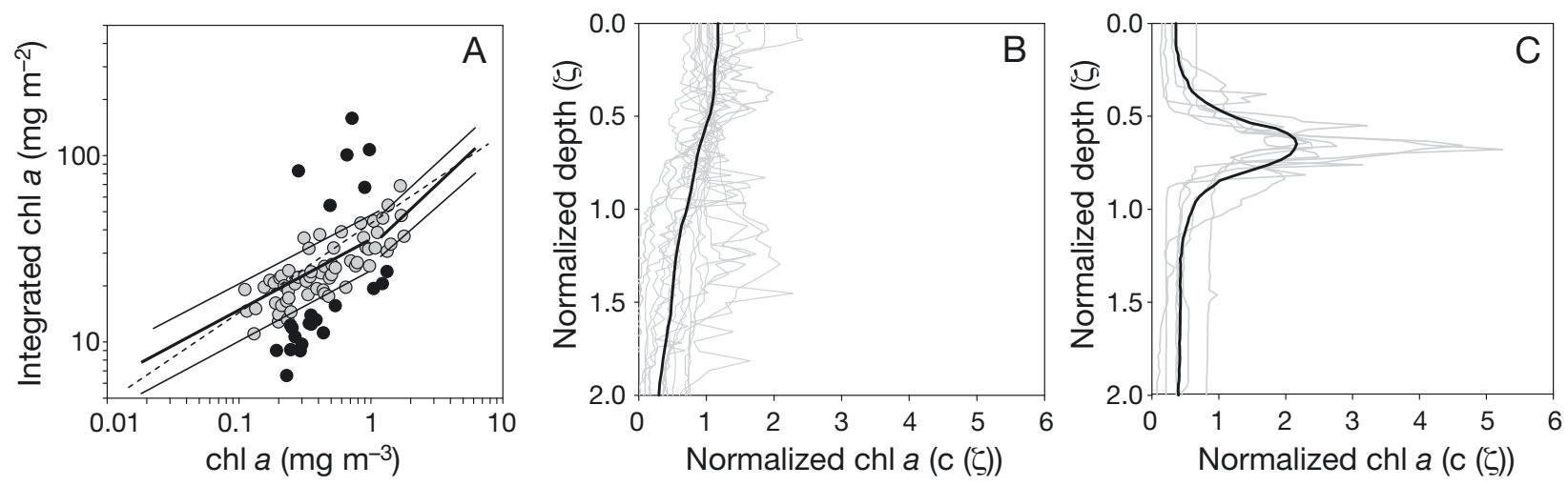

Fig. 10. Relationships between (A) chl a concentration at the surface (depth of euphotic zone $\div 4.6$ ) and chl a concentration integrated over the euphotic zone, showing the present data set (all circles) relative to global regression lines for stratified Case I waters (Morel \& Berthon 1989 = dashed line; Uitz et al. 2006 = thick solid lines with $95 \%$ confidence interval provided as thin solid lines). Vertical profiles (gray lines in B,C) of normalized (following Uitz et al. 2006) chl $a$ concentration $(\mathrm{c}(\zeta)=\mathrm{chl} a$ at depth $\mathrm{z} /$ mean chl $a$ in euphotic zone) and depth $(\zeta=\operatorname{depth}[\mathrm{m}] /$ depth of the $1 \%$ of surface irradiance) presented for groups of stations (black circles in A), which are (B) below and (C) above the $95 \%$ confidence interval determined by Uitz et al. (2006). Thick black lines in (B) and (C): average of all profiles shown 
the estimation of primary production. Pending the detailed results of our ongoing process-oriented investigation into the matter, 3 large-scale emergent properties suggest that SCM are important for primary production (see also Cullen 1982 and Lee \& Whitledge 2005) in seasonally ice-free waters of the Arctic Ocean.

First, the frequency distribution of relative irradiance (Fig. 4A) and the detailed sections (Fig. 5) and dimensionless profiles (Fig. 10C) of chl a show that Arctic SCM are more pronounced and thrive higher in the euphotic zone (3 to $10 \%$ light level) than their counterparts for stratified oceanic waters of the world ocean ( $\leq 1 \%$ light level; Uitz et al. 2006, Pommier et al. 2009). Under the assumption phytoplankton in the SCM is light limited, then photosynthesis would respond linearly to light at low irradiance (e.g. in the lower euphotic zone; near $1 \%$ light level). As such, the relative share of the SCM in total water column primary production in the Canadian Arctic could possibly be an order of magnitude higher than at lower latitudes (e.g. primary production estimated between 12 and $60 \mathrm{mg} \mathrm{C} \mathrm{m}^{-3} \mathrm{~d}^{-1}$ at the SCM depth in Arctic and subarctic regions and between 1.5 and $<15 \mathrm{mg} \mathrm{C} \mathrm{m}^{-3}$ $\mathrm{d}^{-1}$ in North Atlantic Ocean and North Pacific subtropical gyre; Steele \& Yentsch 1960, Steele 1964, Rysgaard et al. 1999, Miller 2004, Mundy et al. 2009, Pommier et al. 2009). This distinction arises because the upper mixed layer is relatively thin and stable in the former, allowing SCM to form in the upper euphotic zone early in the growth season (Tremblay et al. 2008, Mundy et al. 2009).

Second, in a companion study, Tremblay et al. (2009) observed that the numerical contribution of diatoms was up to 10 times higher in the lower euphotic zone (i.e. at the SCM depth) than in the upper mixed layer at stations where a SCM was well defined. Booth et al. (2002) also reported a strong dominance of the SCM by Chaetoceros socialis in northern BB during July. In our study, spatial and inter-annual differences in assemblage composition were related to nutrients and physical properties at the SCM (Fig. 9). Centric diatoms, especially of the genus Chaetoceros, tended to dominate at high $\mathrm{NO}_{3}{ }^{-}$concentrations, whereas flagellates and dinoflagellates tended to take over when water temperature, $\mathrm{NH}_{4}{ }^{+}$concentration and the strength of the pycnocline were high (see also Tremblay et al. 2009). The large size of SCM diatoms (cells $>20 \mu \mathrm{m}$; Lee \& Whitledge 2005, Tremblay et al. 2009) relative to the taxa that dominate higher up in the water column (cells $<10 \mu \mathrm{m}$; Lee \& Whitledge 2005, Tremblay et al. 2009) contributes to the coincidence between the SCM and the SBM in northern BB. Because these communities also thrive higher in the euphotic zone than their counterparts in oligotrophic gyres, they can accumulate enough carbon to maintain a SBM.
Last, the maximum quantum yield of photochemistry for photosystem II $\left(F_{\mathrm{v}} / F_{\mathrm{m}}\right)$ was generally high (median: 0.56 ) in the SCM, implying that the local phytoplankton communities were photosynthetically competent. The good vertical correspondence between the SCM and the degree of $\mathrm{O}_{2}$ supersaturation (Figs. 3 \& 6) implies that oxygenic photosynthesis at or in the vicinity of the SCM was sufficiently high to offset total community respiration, even at low irradiances.

The conceptual model that emerges from our findings and previous ones is that phytoplankton initially develop in the surface layer, where mineralization and mixing processes during winter replenish the inventory of $\mathrm{NO}_{3}^{-}$. The size of this inventory, however, differs greatly between the various regions. In northern $\mathrm{BB}$, surface concentrations at the end of winter are relatively high (up to $10 \mu \mathrm{M}$; Tremblay et al. 2002), whereas they are much lower in the BS (3 to $4 \mu \mathrm{M})$. In the latter, a marked nutricline is already present at $\sim 25 \mathrm{~m}$ prior to the onset of the growth season. Nitrate is readily consumed in the upper mixed layer and the SCM forms very early at the time of ice breakup, after which diatoms lower the nutricline deeper into the upper halocline (Tremblay et al. 2008, Mundy et al. 2009) until light is insufficient to support net growth (i.e. compensation depth; Klausmeier \& Litchman 2001).

The mechanism(s) controlling the vertical position, thickness and seasonal persistence of the SCM in the Arctic Ocean remain to be elucidated, but previous studies demonstrated the importance of turbulent mixing (Zakardjian et al. 2000, Huisman et al. 2006) and variations in the buoyancy of diatoms (physiologically induced changes in response to nutrient supply and decrease of irradiance at the bottom of the euphotic zone: Steele \& Yentsch 1960, Cullen 1982). The latter is presumably important in the strongly stratified BS. Surface communities composed largely of nano- and picophytoplankton (Tremblay et al. 2009) with some degree of motility presumably thrive reasonably well on 'recycled' nitrogen, consistent with the generally high $F_{\mathrm{v}} / F_{\mathrm{m}}$ near the surface (Fig. 8).

\section{Biogeochemical significance of the SCM}

The nitrogen initially taken up as $\mathrm{NO}_{3}^{-}$by phytoplankton at the SCM may follow several paths, including (1) release as $\mathrm{NO}_{2}{ }^{-}$by diatoms, (2) assimilation into organic matter followed by vertical export or local recycling as $\mathrm{NH}_{4}{ }^{+}$or dissolved organic nitrogen. The latter occurs via exudation or waste production by consumers and can be taken up again to fuel the 'regenerated' component of primary production. Given the 
highly productive nature of the North Water in BB (Tremblay et al. 2002), the relatively large inventories of $\mathrm{NH}_{4}{ }^{+}$beneath the SCM are also consistent with a progressive build up during the growth season, a result of export and ammonification during the microbial degradation of particulate organic matter and zooplankton excretion (Tremblay et al. 2006).

The positive relationship between the depth of the nitracline and the depth of the SCM at the synoptic scale (Figs. 6C \& 7C) and throughout the growth season (Tremblay et al. 2008) suggests that $\mathrm{NO}_{3}{ }^{-}$accounts for a significant share of their nitrogen demand. The SCM more or less acts as a boundary, effectively preventing the upward diffusion of $\mathrm{NO}_{3}{ }^{-}$into the upper euphotic zone (Fig. 6C). This is consistent with previous reports that the SCM progressively lowers the nitracline during the growth season, accounting for at least half of the $\mathrm{NO}_{3}{ }^{-}$drawdown after ice break-up (Tremblay et al. 2008, Mundy et al. 2009). On a daily basis, however, local recycling may contribute a significant part of the nitrogen demand, which is consistent with the very low concentrations of $\mathrm{NH}_{4}{ }^{+}$at and above the SCM throughout the Canadian Arctic.

The oxidation of $\mathrm{NH}_{4}^{+}$to $\mathrm{NO}_{2}^{-}$by ammonia-oxydizing bacteria or archea and to $\mathrm{NO}_{3}{ }^{-}$by nitrite oxydizers also supplies 'recycled' nitrogen to phytoplankton (Ward 2002, Konneke et al. 2005). Nitrification can account for a substantial share of the $\mathrm{NO}_{3}{ }^{-}$demand in other stratified waters (e.g. Raimbault et al. 1999, Yool et al. 2007) and is hypothesized to supply a third of the $\mathrm{NO}_{3}{ }^{-}$renewal in the upper mixed layer of the coastal BS during winter (Tremblay et al. 2008). These issues have important implications for the operational estimation of new production (sensu Dugdale \& Goering 1967) and the biogeochemical significance of the SCM. Striking spatial contrasts in the accumulation of $\mathrm{NH}_{4}^{+}$ and $\mathrm{NO}_{2}^{-}$at the base of the euphotic zone (Fig. 6D,E), which necessarily arises from imbalances between inputs and losses, provide additional insights into the ecology of Arctic SCM.

The well-defined maxima of $\mathrm{NH}_{4}{ }^{+}$and $\mathrm{NO}_{2}^{-}$at or immediately below the SCM in the southeast BS and AG were conspicuously absent in the eastern Canadian Arctic, which can be explained by physical and biological processes.

In the western Canadian Arctic, $N^{2}$ at and underneath the pycnocline is higher than in northern $\mathrm{BB}$ (Fig. 6A). This distinction is well rendered by $\mathrm{NO}_{3}{ }^{-}$, whose concentrations jump from 2 to $10 \mu \mathrm{M}$ over a distance of $15 \mathrm{~m}$ in the AG versus $100 \mathrm{~m}$ in northern $\mathrm{BB}$. In the former, the strong stratification limits the turbulent diffusion of solutes away from the SCM. In $\mathrm{BB}$ and the Atlantic end of LS, mixing is more likely to produce diffuse vertical structures such as those observed for $\mathrm{NH}_{4}{ }^{+}$and $\mathrm{NO}_{2}^{-}$(i.e. biological rates are presumably low relative to physical diffusion). The midnight sun may also have contributed to the absence of a PNM during August 2005 in northern BB, since previous experimental work showed nitrification to be completely inhibited at light:dark cycles exceeding 16:8 h (Horrigan et al. 1981). Under an 8 h light:16 h dark cycle similar to what prevailed in the BS during fall 2006, Horrigan et al. (1981) observed low but measurable daily rates of $\mathrm{NH}_{4}{ }^{+}$oxidation in the euphotic zone. In that study, nitrite oxidizers were particularly sensitive to light and were active only under $24 \mathrm{~h}$ of darkness (Horrigan et al. 1981), which is consistent with the accumulation of $\mathrm{NO}_{2}^{-}$we observed in the euphotic zone.

That $\mathrm{NO}_{2}^{-}$concentrations were high and similar despite a 4 -fold variation in $\mathrm{NH}_{4}{ }^{+}$across the $\mathrm{BS}$ section suggests that PNMs were maintained mostly by lightlimited phytoplankton in the lower trail of the SCM. The PNM was located at the base of the euphotic zone where phytoplankton can take up more $\mathrm{NO}_{3}{ }^{-}$than they can assimilate into organic matter, the rationale being that reducing $\mathrm{NO}_{3}{ }^{-}$to $\mathrm{NO}_{2}{ }^{-}$is energetically cheap compared to reducing $\mathrm{NO}_{2}^{-}$to $\mathrm{NH}_{4}{ }^{+}$(Kiefer et al. 1976, Lomas \& Lipschultz 2006). The $\mathrm{NO}_{2}{ }^{-}$trapped at the physiological bottleneck is released into the water. This scenario is consistent with the positive correlation observed between the concentrations of $\mathrm{NO}_{2}^{-}$and $\mathrm{NO}_{3}^{-}(\mathrm{r}=0.52, \mathrm{p}<0.001)$, which is not likely to be driven mainly by $\mathrm{NO}_{2}^{-}$oxidation since $\mathrm{NO}_{3}^{-}$concentrations were primarily explained by salinity (implying physical processes; $r=0.30, p<0.05$ ).

\section{CONCLUSIONS}

Our observations confirm that photosyntheticallycompetent SCM are nearly widespread in stratified oceanic waters of the Canadian Arctic and Subarctic during late summer and early fall. Since SCM also correspond to maxima of phytoplankton biomass, at least in northern $\mathrm{BB}$, they presumably represent an important source of carbon for the food web and the sediment. In contrast with those of other oceans, Arctic SCM (1) are located relatively high in the euphotic zone, (2) are generally disconnected from the upper mixed layer and, at times, (3) contain a disproportionately high and poorly predictable portion of total biomass in the euphotic zone. These conditions present a unique set of challenges for the estimation of biomass and primary production with orbiting sensors that scrutinize the upper mixed layer. Although previously published global, statistical relationships between surface chl $a$, integrated $\mathrm{chl} a$ and the shape of the vertical chl a profile hold reasonably well for the Canadian Arctic, they can lead to severe underestima- 
tion when the SCM is sharp and intense in clear oceanic waters. Given their prevalence, the repercussions of SCM for the accuracy of remote-sensing estimations of primary production in the Arctic Ocean should be quantified.

By virtue of their longevity and widespread occurrence, SCM in the BS share common traits with those of subtropical oceanic gyres. Prompt depletion of the modest $\mathrm{NO}_{3}{ }^{-}$inventories present in the upper mixed layer at the onset of the productive period drives the early appearance of SCM, whose longevity currently depends on the duration of the ice-free season. The September minimum extent of sea-ice decreased at the mean rate of $9 \%$ between 1978 and 2006 and reached dramatic record lows in 2007 and 2008 as the multiyear ice was largely replaced by seasonal ice (NSIDC 2009). It is likely that a protracted ice-free season will allow SCM to lower the nitracline further and make an increased contribution to annual primary production, except where mixing or upwelling replenish nutrients at the surface.

The relative importance of SCM for water-column primary production and the food web is also likely to increase as freshwater deliveries by rivers, precipitation and glacier melt rise (Wu et al. 2005). Due to the ensuing increase in vertical stability and decrease in convection during seasonal cooling and ice growth, phytoplankton communities in the interior of the Arctic Ocean may come to rely even more on the availability of nutrients at the base of the euphotic zone. The importance of allochthonous versus locally 'recycled' nitrogen for the nutrition of SCM communities remains largely unknown, although our results suggest that nitrification plays a lesser role in the Arctic than in warm oceans. Ongoing investigations into the roles that physical (e.g. mixing, diffusion) and biological (e.g. nitrogen cycling, photo-acclimation, functional diversity and buoyancy-regulation) processes play in the persistence and productivity of SCM will help elucidate their biogeochemical significance in an era of drastic environmental changes.

Acknowledgements. This study was supported by grants to J.E.T., M.P., M.G. and Y.G. from the Canadian Network Centres of Excellence (NCE) ArcticNet, and the Natural Sciences and Engineering Research Council of Canada (NSERC). Partial operating funds for the 'CCGS Amundsen' were provided by the International Joint Ventures Fund of the Canada Foundation for Innovation and the Fonds québécois de la recherche sur la nature et les technologies (FQRNT). We thank the scientists and the crews of the 'CCGS Amundsen' for their invaluable support in the field and the 4 reviewers for their constructive comments, and are grateful to M. E. Rail, V. Lago and P. Guillot for collecting and processing the CTD data. This is a contribution to the scientific programs of ArcticNet, Québec-Océan and the Canada Research Chair on the response of Arctic Marine Ecosystems to Climate Change.

\section{LITERATURE CITED}

Anderson GC (1969) Subsurface chlorophyll maximum in the Northeast Pacific Ocean. Limnol Oceanogr 14:386-391

Arrigo KR, Dijken G, Pabi S (2008) Impact of a shrinking Arctic ice cover on marine primary production. Geophys Res Lett 35:L19603, doi:10.1029/2008GL035028

Ban A, Aikawa S, Hattori H, Sasaki H and others (2006) Comparative analysis of photosynthetic properties in ice algae and phytoplankton inhabiting Frankling Bay, the Canadian Arctic, with those mesophilic diatoms during CASES 03-04. Polar Biosci 19:11-28

Beckmann A, Hense I (2007) Beneath the surface: characteristics of oceanic ecosystems under weak mixing conditions-a theoretical investigation. Prog Oceanogr 75: 771-796

Bérard-Therriault L, Poulin M, Bossé L (1999) Guide d'identification du phytoplancton marin de l'estuaire et du golfe $\mathrm{du}$ Saint-Laurent incluant également certains protozoaires. Publ Spec Can Sci Halieut Aquat 128. Conseil national de recherche du Canada, Ottawa (in French with English summary)

> Booth BC, Larouche P, Belanger S, Klein B, Amiel D, Mei ZP (2002) Dynamics of Chaetoceros socialis blooms in the North Water. Deep-Sea Res II 49:5003-5025

Calbet A, Prairie YT (2003) Mesozooplankton grazing and primary production: reply to the comment by laws. Limnol Oceanogr 48:1359-1362

Carmack EC, Chapman DC (2003) Wind-driven shelf/basin exchange on an Arctic shelf: the joint roles of ice cover extent and shelf-break bathymetry. Geophys Res Let 30: 1778, doi:10.1029/2003GL017526

Carpenter JH (1965) The accuracy of the Winkler method for dissolved oxygen. Limnol Oceanogr 10:135-140

Chung PC, Gardner WD, Landry MR, Richardson MJ, Walsh ID (1998) Beam attenuation by microorganisms and detrital particles in the equatorial Pacific. J Geophys Res 103: 12669-12681

> Coon TG, Lopez M, Richerson J, Powell TM, Goldman CR (1987) Summer dynamics of the deep chlorophyll maximum in Lake Tahoe. J Plankton Res 9:327-344

Cota GF, Pomeroy LR, Harrison WG, Jones EP, Peters F, Sheldon WM, Weingartner TR (1996) Nutrients, primary production and microbial heterotrophy in the southeastern Chukchi Sea: Arctic summer nutrient depletion and heterotrophy. Mar Ecol Prog Ser 135:247-258

Cullen JJ (1982) The deep chlorophyll maximum: comparing vertical profiles of chlorophyll a. Can J Fish Aquat Sci 39: 791-803

> Dolan JR, Marrasé C (1995) Planktonic ciliate distribution relative to a deep chlorophyll maximum: Catalan Sea, N.W. Mediterranean, June 1993. Deep-Sea Res I 42:1965-1987

> Dugdale RC, Goering JJ (1967) Uptake of new and regenerated forms of nitrogen in primary productiviy. Limnol Oceanogr 12:196-206

Falkowski PG, Kiefer DA (1985) Chlorophyll a fluorescence in phytoplankton: relationship to photosynthesis and biomass. J Plankton Res 7:715-731

Fennel K, Boss E (2003) Subsurface maxima of phytoplankton and chlorophyll: steady-state solutions from a simple model. Limnol Oceanogr 48:1521-1534

Grasshoff K, Kremling K, Ehrhardt M (eds) (1999) Methods of seawater analysis, 3rd edn. Wiley-VCH, New York. NY

> Heiskanen AS, Keck A (1996) Distribution and sinking rates of phytoplankton, detritus, and particulate biogenic silica in the Laptev Sea and Lena River (Arctic Siberia). Mar Chem 53:229-245 
Hirche HJ, Baumann MEM, Kattner G, Gradinger R (1991) Plankton distribution and the impact of copepod grazing on primary production in Fram Strait, Greenland Sea. J Mar Syst 2:477-494

Hodges BA, Rudnick DL (2004) Simple models of steady deep maxima in chlorophyll and biomass. Deep-Sea Res I 51: 999-1015

Holm-Hansen O, Hewes CD (2004) Deep chlorophyll-a maxima (DCMs) in Antarctic waters: I. Relationships between DCMs and the physical, chemical, and optical conditions in the upper water column. Polar Biol 27:699-710

> Holmes RM, Aminot A, Kerouel R, Hooker BA, Peterson JB (1999) A simple and precise method for measuring ammonium in marine and freshwater ecosystems. Can J Fish Aquat Sci 56:1801-1808

Horrigan SG, Carlucci AF, Williams RG (1981) Light inhibition of nitrification in sea-surface films. J Mar Res 39: 557-565

Huisman J, Pham Thi NN, Karl DM, Sommeijer B (2006) Reduced mixing generates oscillations and chaos in the oceanic deep chlorophyll maximum. Nature 439:322-325

Huszar V, Kruk C, Nina C (2003) Steady-state assemblages of phytoplankton in four temperate lakes (NE USA). Hydrobiologia 502:97-109

Jones EP, Swift JH, Anderson LG, Lipizer M and others (2003) Tracking Pacific water in the North Atlantic Ocean. J Geophys Res 108:1-10

Kiefer DA, Olson RJ, Holm-Hansen O (1976) Another look at the nitrite and chlorophyll maxima in the central North Pacific. Deep-Sea Res 23:1199-1208

Klausmeier CA, Litchman E (2001) Algal games: the vertical distribution of phytoplankton in poorly mixed water columns. Limnol Oceanogr 46:1998-2007

Knapp GP, Stalcup MC, Stanley RJ (1990) Automated oxygen titration and salinity determination. Technical report WHOI-90-35. Woods Hole Oceanographic Institution, Woods Hole, MA

Konneke M, Bernhard AE, de la Torre JR, Walker CB, Waterbury JB, Stahl DA (2005) Isolation of an autotrophic ammonia-oxidizing marine archaeon. Nature 437: 543-546

Laws EA, Archie JW (1981) Appropriate use of regression analysis in marine biology. Mar Biol 65:13-16

Lee SH, Whitledge TE (2005) Primary and new production in the deep Canada Basin during summer 2002. Polar Biol 28: 190-197

Lomas MW, Lipschultz F (2006) Forming the primary nitrite maximum: nitrifiers or phytoplankton? Limnol Oceanogr 51:2453-2467

Lund JWG, Kipling C, Le Cren ED (1958) The inverted microscope method of estimating algal numbers and the statistical basis of estimations by counting. Hydrobiologia 11: $143-170$

Mann KH, Lazier JRN (2006) Dynamics of marine ecosystems: biological-physical interactions in the oceans. Blackwell Publishing, Malden, MA

Martini IP (1986) Canadian inland seas. Elsevier, New York, NY

Miller CB (2004) Biological oceanography. Blackwell Science Ltd, Oxford

Morel A, Berthon JF (1989) Surface pigments, algal biomass profiles, and potential production of the euphotic layer: relationships reinvestigated in view of remote-sensing applications. Limnol Oceanogr 34:1545-1562

Mundy C-J, Gosselin M, Ehn J, Gratton Y, and others (2009) Contribution of under-ice primary production to an iceedge upwelling phytoplankton bloom in the Canadian
Beaufort Sea. Geophys Res Lett 36:L17601, doi:10.1029/ 2009GL038837

NSIDC (National Snow and Ice Data Center (2009) State of the cryosphere: sea ice. Available at http://nsidc.colorado. edu/sotc/sea_ice.html (accessed 19 June, 2009)

Parsons TR, Maita Y, Lalli CM (1984) A manual of chemical and biological methods for seawater analysis. Pergamon Press, Toronto

Pommier J, Gosselin M, Michel C (2009) Size-fractionated phytoplankton production and biomass during the decline of the northwest Atlantic spring bloom. J Plankton Res 31: 429-446

Prinsenberg SJ (1986) On the physical oceanography of Foxe Basin. In: Martini IP (ed) Canadian inland seas. Elsevier Oceanography Series, New York, NY, p 217-236

Raimbault P, Slawyk G, Boudjellal B, Coatanoan C and others (1999) Carbon and nitrogen uptake and export in the equatorial Pacific at $150^{\circ} \mathrm{W}$ : evidence of an efficient regenerated production cycle. J Geophys Res 104: 3341-3356

Rysgaard S, Nielsen TG, Hansen BW (1999) Seasonal variation in nutrients, pelagic primary production and grazing in a high-Arctic coastal marine ecosystem, Young Sound, Northeast Greenland. Mar Ecol Prog Ser 179:13-25

Sakshaug E (2004) Primary and secondary production in the Arctic seas. In: Stein R, Macdonald RW (eds) The organic carbon cycle in the Arctic Ocean. Springer-Verlag, Berlin, p 57-81

Sharples J, Moore CM, Rippeth TP, Holligan PM, Hydes DJ, Fisher NR, Simpson JH (2001) Phytoplankton distribution and survival in the thermocline. Limnol Oceanogr 46: 486-496

Sharples J, Tweddle JF, Green JAM, Palmer MR and others (2007) Spring-neap modulation on internal tide mixing and vertical nitrate fluxes at a shelf edge in summer. Limnol Oceanogr 52:1735-1747

Steele JH (1964) A study of production in the Gulf of Mexico. J Mar Res 22:211-222

Steele JH, Yentsch CS (1960) The vertical distribution of chlorophyll. J Mar Biol Assoc UK 39:217-226

Stein R, Macdonald RW (2004) The organic carbon cycle in the Arctic Ocean. Springer-Verlag, Berlin

Tomas CR (1997) Identifying marine phytoplankton. Academic Press, San Diego, CA

Tremblay JÉ, Gratton Y, Carmack EC, Payne CD, Price NM (2002) Impact of the large-scale Arctic circulation and the North Water Polynya on nutrient inventories in Baffin Bay. J Geophys Res 107:3112, doi:10.1029/2000JC000595

Tremblay JÉ, Michel C, Hobson KA, Gosselin M, Price NM (2006) Bloom dynamics in early opening waters of the Arctic Ocean. Limnol Oceanogr 51:900-912

> Tremblay JÉ, Simpson K, Martin J, Miller L, Gratton Y, Barber D, Price NM (2008) Vertical stability and the annual dynamics of nutrients and chlorophyll fluorescence in the coastal, southeast Beaufort Sea. J Geophys Res 113: C07S90, doi:10.1029/2007JC004547

- Tremblay G, Belzile C, Gosselin M, Poulin M, Roy S, Tremblay JÉ (2009) Late summer phytoplankton distribution along a $3500 \mathrm{~km}$ transect in Canadian Arctic waters: strong numerical dominance by picoeukaryotes. Aquat Microb Ecol 54:55-70

Uitz J, Claustre H, Morel A, Hooker SB (2006) Vertical distribution of phytoplankton communities in open ocean: an assessment based on surface chlorophyll. J Geophys Res 111:C08005, doi:10.1029/2005JC003207

> Vidussi F, Roy S, Lovejoy C, Gammelgaard M and others (2004) Spatial and temporal variability of the phytoplank- 
ton community structure in the North Water Polynya, investigated using pigment biomarkers. Can J Fish Aquat Sci 61:2038-2052

Wallace DWR, Minnett PJ, Hopkins TS (1995) Nutrients, oxygen, and inferred new production in the Northeast Water Polynya, 1992. J Geophys Res 100:4323-4340

Ward BB (2002) Nitrification in aquatic systems. In: Capone DG (ed) Encyclopedia of environmental microbiology. Wiley \& Sons, New York, NY, p 2144-2167

Weiss RF (1970) The solubility of nitrogen, oxygen and argon in water and seawater. Deep-Sea Res 17:721-735

> Williams WJ, Carmack EC (2008) Combined effect of wind-

Editorial responsibility: Alain Vézina,

Dartmouth, Canada forcing and isobath divergence on upwelling at Cape Bathurst, Beaufort Sea. J Mar Res 66:645-663

Wu P, Wood R, Stott P (2005) Human influence on increasing Arctic river discharges. Geophys Res Lett 32:L02703, doi: 10.1029/2004GL021570

Yool A, Martin AP, Fernández C, Clark DR (2007) The significance of nitrification for oceanic new production. Nature 447:999-1002

Zakardjian BA, Gratton Y, Vézina AF (2000) Late spring phytoplankton bloom in the Lower St. Lawrence Estuary: the flushing hypothesis revisited. Mar Ecol Prog Ser 192: $31-48$

Submitted: July 23, 2009; Accepted: May 17, 2010

Proofs received from author(s): August 10, 2010 